\title{
Development of Nested Polymerase Chain Reaction Detection of Mycosphaerella spp. and Its Application to the Study of Leaf Disease in Eucalyptus Plantations
}

\author{
M. Glen, A. H. Smith, S. R. H. Langrell, and C. L. Mohammed
}

First, second, and fourth authors: Forest Biosecurity and Protection, Ensis, Private Bag 12, Hobart, Tasmania, Australia, 7001; second and fourth authors: CRC for Sustainable Production Forestry, University of Tasmania, Private Bag 12, Hobart, Tasmania, Australia, 7001; and third author: CSIRO Forestry and Forest Products, Private Bag 5, Wembley, Western Australia, 6913.

Current address of S. R. H. Langrell: European Commission, Directorate General Joint Research Centre, Institute for Health and Consumer Protection, I-21020 Ispra, Italy.

Accepted for publication 9 August 2006.

\begin{abstract}
Glen, M., Smith, A. H., Langrell, S. R. H., and Mohammed, C. L. 2007. Development of nested polymerase chain reaction detection of Mycosphaerella spp. and its application to the study of leaf disease in Eucalyptus plantations. Phytopathology 97:132-144.

Mycosphaerella leaf disease (MLD) is a serious disease of two of the major eucalypt species grown in temperate regions worldwide, Eucalyptus globulus and E. nitens. More than 30 species of Mycosphaerella have been reported on eucalypts worldwide. Accurate, rapid, and early discrimination of Mycosphaerella spp. causing crown damage to E. globulus and $E$. nitens will assist the development of sustainable management strategies. This study describes the development, and incorporation in a nested polymerase chain reaction (PCR) approach, of specific primers for the detection and identification of Mycosphaerella spp. commonly reported from leaf lesions of E. globulus and E. nitens in Australia. Primer design was assisted by sequence alignment and phylogenetic analysis of 165 nonredundant sequences from the nuclear ribosomal DNA internal transcribed spacer regions of Mycosphaerella and related species. Phylogenetic analysis revealed very high sequence similarity for two taxon groups, Mycosphaerella grandis and M. parva, and M. vespa, M. ambi-

phylla, and M. molleriana, and primers were designed to differentiate each of the two groups. Three other species, M. cryptica, M. nubilosa, and $M$. tasmaniensis, were distinct and distinguished by species-specific primers. In double-blind trials, the detection test accurately and rapidly identified Mycosphaerella spp. in cultures and discriminated against other pathogens that co-occur in or on Eucalyptus leaves, thereby verifying its reliability. The detection test has an internal amplification control in the first-round PCR with fungal-specific primers to raise confidence in test results, particularly to highlight negative results due to PCR inhibition. When applied to DNA extracted from leaf or stem samples either as multiple or single lesions, it detected and identified up to five Mycosphaerella spp. or taxon groups in both positively identified and in young (putative) MLD lesions. The samples were $20 \mathrm{~mm}^{2}$ or larger in surface area and were collected while undertaking disease rating assessments in an experimental investigation of Eucalyptus plantations and regrowth forest. Using nested PCR detection, Mycosphaerella spp. were positively identified in 2 days, 1 to 5 months earlier than by classical methods, demonstrating the potential application of this detection test to the early discrimination of MLD components in ecological, epidemiological, and genetic investigations.
\end{abstract}

Eucalyptus spp. are a major global hardwood pulp crop. Mycosphaerella spp. cause severe leaf diseases of temperate Eucalyptus plantations in wetter areas of Australia and serious disease in New Zealand, South Africa, Spain, and some regions of Chile (19). Many species appear to have spread to other temperate regions from Australia, and species that also occur in the Australian subtropics appear to have spread to Indonesia, Vietnam, China, and South America $(21,58,62)$. Indigenous temperate Australian forests have mixed eucalypt species where Mycosphaerella leaf disease (MLD) generally is of minor significance, except in coppice regrowth in certain Western Australian forests $(1,14)$. In southern Australia, MLD in plantations appears to be caused principally by Mycosphaerella nubilosa and $M$. cryptica, although M. vespa, M. tasmaniensis, M. parva, and M. grandis occur frequently. $M$. marksii and other species are encountered less often $(13,49,51,52,60)$. The most damaging are reported to be $M$. nubilosa and $M$. cryptica (10-12,14,25,59-62), which cause the most severe leaf disease, resulting in significant crown damage of E. globulus, E. nitens, and their hybrids $(30,39)$, the most widely

Corresponding author: M. Glen; E-mail address: Morag.Glen@csiro.au

DOI: 10.1094/PHYTO-97-2-0132

(C) 2007 The American Phytopathological Society grown temperate plantation species. Crown damage in E. globulus in Australia has been reported to range from $10 \%$ leaf necrosis to complete defoliation and tree death in locations strongly conducive to disease development $(22,23,50,52)$. MLD has restricted the use of commercially desirable eucalypt species in Australia, New Zealand, and South Africa (28).

Currently, MLD is detected visually by lesion characteristics that also are used in crown damage assessment of plantations (71). Many foliar diseases that have much lower impact also produce symptoms similar to MLD and are difficult to distinguish without experience or training. MLD identification may be confirmed using conventional methods. Conventional methods for positive identification of these and other leaf pathogens involve waiting until lesions produce "typical" reproductive structures or forms, isolating them, and identification of putative pathogens using taxonomic criteria. A challenge for those evaluating Mycosphaerella spp. affecting eucalypts is that reproductive structures may or may not form in leaves or cultures and, often, the most readily available identifying characteristics, such as germinating ascospores, are also taxonomically ambiguous $(10,15,49$, 51,59-62). In addition, pseudothecia do not form in axenic cultures of most species and are found only in older lesions or, for a few species, on inoculated aseptic leaves in culture $(59,60)$. Identification is further confounded by the fact that more than one 
Mycosphaerella spp. may be present in a single lesion $(43,62)$. Other limitations of conventional methods include low isolation frequencies of all or even most Mycosphaerella spp. from lesions. Detailed sampling does not always deliver all of the Mycosphaerella spp. present in each lesion. Hence, crown damage assessment based on lesions is not necessarily attributable to a particular Mycosphaerella spp.

Molecular detection of plant pathogens is used in many agricultural spheres to assist decision support systems. These include immunological and DNA and polymerase chain reaction (PCR)based methods. Immunological detection of Mycosphaerella brassicicola from spore traps has been developed to rationalize pesticide applications within crop protection programs (42). However, pathogen discrimination is still dependent on spore production, which may occur at a late stage in development in the disease cycle and by which stage prophylactic intervention may not be a management option. Furthermore, fungicide use may be financially or environmentally prohibitive in tree plantations. Detection at an earlier stage in the fungal life-cycle would be preferable and may permit development of silvicultural options to prevent disease or reduce disease severity $(9,11,52)$. PCR-based methods exploit genetic sequence differences to provide early, rapid, specific, and sensitive detection and identification of pathogens of concern regardless of the presence of reproductive structures. PCR amplification using species-specific primers has been widely used for disease diagnosis in humans, other animals, and plants $(2,67)$. Specific PCR tests have been developed for M. graminicola (Septoria tritici) in wheat (27) and to distinguish $M$. fijiensis and $M$. musicola from banana leaves (40). PCR detection may target specific genes or anonymous products, such as microsatellites, random amplified polymorphic DNA, or amplified fragment length polymorphism fragments $(35,67,68,72)$. In order to provide simultaneous discrimination for several Mycosphaerella spp. of eucalypts with high reproducibility and reliability, a wellcharacterized DNA region which is likely to be highly stable must be targeted. There are more than 30 species of Mycosphaerella on Eucalyptus spp., and related anamorphs increase this number to over $50(5,6,15,17,18,49)$. In wheat, the $M$. graminicola-specific PCR amplifies a fragment of the $\beta$-tubulin gene (27). However, many more species occur in eucalypts than on wheat, and few $\beta$ tubulin sequences are currently available for eucalypt species. The specific primers for $M$. fijiensis and M. musicola (banana pathogens) were designed to sequence divergence within internal transcribed spacer (ITS)1 (40). In addition, molecular phylogenetic studies in the families Mycosphaerellaceae on Myrtaceae have been based mainly on ITS1 and ITS2 sequences $(19,20$, $33,62,64,70)$. These studies have provided reliable characters for the discrimination of species for which morphological characters such as spore dimensions are variable within species and overlap among species (62), leading to taxonomic confusion and frequent misidentifications. The value of ITS sequence data is attested to by the numerous Mycosphaerella sequences available on public databases. Multiple sequences are available for species causing serious diseases of industrial crops, allowing comparison of geographically diverse isolates from different host species. In addition to providing interspecific discrimination, the ribosomal RNA genes, including the ITS regions, are multicopy, assisting in sensitive detection from plant material. Sensitivity is essential as lesions may have mixtures of many fungal species in addition to several Mycosphaerella spp. A PCR test based on ITS sequences exists for some Mycosphaerella spp. on eucalypts; however, the published test requires a restriction digestion after PCR, with discrimination based on fragment size (43), adding considerably to the processing and analysis time. Analysis of restriction fragments also may be confounded when multiple species are present, as is often the case in MLD.

Therefore, the primary aim of this investigation was to develop PCR-based systems for direct detection and identification of several
Mycosphaerella spp. from lesions of all ages in eucalypt species as a research tool aimed at refining current knowledge of epidemiology, ecology, and host resistance and to provide the potential for certification of disease-free germ plasm. Although the tests developed here were primarily for use on Eucalyptus spp. leaves and stems, they also were intended to be applicable to a wider range of woody species that are potential hosts for Mycosphaerella spp. For example, other members of the family Myrtaceae, members of other Myrtales families, and species of the family Proteaceae are actual or potential hosts that co-occur naturally throughout the landscape in Australia with Eucalyptus spp. Plantations are grown in close proximity to natural vegetation harboring Mycosphaerella spp. in Australia, South Africa, most probably South America, which shares a Gondwanan origin, and Indonesia. In addition to detecting Mycosphaerella spp. directly from leaves, a detection system also could be used to verify whether samples collected or isolated during earlier surveys belong to the species or taxon group in which they had been identified according to the taxonomic criteria at the time.

PCR, although fast, sensitive, and capable of being automated, is not without problems. These include enzyme inhibition by substances present in the template DNA, which may cause false negative results. Plant material is particularly notorious for PCR inhibitor compounds, many of which often are co-precipitated during DNA extraction (45). Strategies to overcome PCR inhibition and increase confidence in negative results include using a range of DNA template dilutions (40), spiking of negative samples (40), buffer additions during the DNA extraction process $(4,34,63)$ magnetic DNA capture $(4,45,63)$, post-extraction purification (44), and the use of alternative polymerases (3). In the interests of speed, economy, and wide applicability of the tests, it is desirable to avoid repetitious assays or lengthy and involved DNA purification techniques. A rapid, simple DNA purification method based on binding of DNA to silica in the presence of chaotropic salts (31) avoids the use of toxic and volatile reagents and has been used extensively in our laboratory for obtaining amplifiable DNA from a wide range of material. Nested PCR also has been used to amplify DNA containing inhibitors from plant material $(53,75)$. Because none of these strategies for overcoming PCR inhibition were completely successful, detection of PCR inhibition is important to raise confidence in negative results. This can be achieved by the use of internal amplification controls (IACs). Amplification of endogenous IACs using a different primer pair has been shown to be unreliable in detecting PCR inhibition (37); therefore, we constructed an exogenous IAC that can be added at a controlled concentration to each sample in the first round of a nested PCR. Specific primers were used in the second-round PCR to detect the presence of five of the most commonly reported Mycosphaerella spp. in southern Australian plantations. The results of a survey of Mycosphaerella spp. in an E. globulus plantation in northern Tasmania to establish a baseline of the species present prior to the setting up of experimental trials also are presented here. The increased coverage, spatial resolution, and accuracy provided by using the detection test as a survey tool for Mycosphaerella spp. are discussed.

\section{MATERIALS AND METHODS}

Fungal material. Cultures (Table 1) were maintained on $2 \%$ malt extract agar. Nonviable cultures up to 10 years old also were used for DNA extraction. Standard reference cultures for each of the target species were nominated based on the most reliably identified material available. These were $M$. cryptica (AA/1/3/10), morphologically identified by Milgate (51), ITS sequenced here, sequence consistent with sequences in GenBank for nine other $M$. cryptica isolates; $M$. grandis $(\mathrm{Q} / 1 / 1 / 1)$, morphologically identified by Milgate in collaboration with A. J. Carnegie, and ITS 
sequenced (51), sequence identical with that of AC165, neotype material from A. J. Carnegie; $M$. nubilosa (Z/1/1/11), morphologically identified by Milgate (51), ITS sequenced, and consistent with 13 other sequences in GenBank; M. tasmaniensis (STE-U1555), an ex-type culture from Tasmania (21); and
M. vespa (BS/3/2/1), morphologically identified by Milgate in collaboration with A. J. Carnegie, and ITS sequenced (51). These cultures have been deposited in the Department of Agriculture Western Australia Plant Pathogen Collection (WDCM77).

TABLE 1. Fungal cultures used to test species-specific primers

\begin{tabular}{|c|c|c|c|}
\hline Species & Code $^{\mathrm{a}}$ & Host & Origin \\
\hline Botryosphaeria sp. & WA36 & Eucalyptus wandoo & Western Australia \\
\hline Cryptosporiopsis eucalypti & $\mathrm{I} 00108 \mathrm{a}^{\mathrm{b}}$ & E. camaldulensis & Queensland \\
\hline Cylindrocladium retaudii & $\mathrm{I} 00150^{\mathrm{b}}$ & E. urophylla & Queensland \\
\hline Mycosphaerella africana & CBS680.95 & E. viminalis & South Africa \\
\hline \multirow{15}{*}{ M. cryptica } & $\mathrm{AA} / 1 / 3 / 10^{\mathrm{e}}$ & E. globulus & Tasmania \\
\hline & $\mathrm{NZ301 \textrm {H } ^ { \mathrm { e } }}$ & E. nitens & New Zealand \\
\hline & E7444a $a^{\mathrm{f}}$ & E. pilularis & New South Wales \\
\hline & $\mathrm{I} 00205^{\mathrm{b}}$ & E. globulus & Victoria \\
\hline & $\mathrm{I} 00207^{\mathrm{b}}$ & E. globulus & Victoria \\
\hline & I00208b & E. globulus & Victoria \\
\hline & $\mathrm{I} 00210^{\mathrm{b}}$ & E. globulus & Victoria \\
\hline & $\mathrm{I} 00214^{\mathrm{b}}$ & E. globulus & Victoria \\
\hline & I00216 & E. globulus & Victoria \\
\hline & $\mathrm{I} 00217^{\mathrm{b}}$ & E. globulus & Victoria \\
\hline & $\mathrm{I} 00225^{\mathrm{b}}$ & E. obliqua & Victoria \\
\hline & $\mathrm{I} 00226^{\mathrm{b}}$ & E. obliqua & Victoria \\
\hline & $\mathrm{I} 00234^{\mathrm{b}}$ & E. globulus & Victoria \\
\hline & $\mathrm{I} 00235^{\mathrm{b}}$ & E. cypellocarpa & New South Wales \\
\hline & $\mathrm{I} 00236^{\mathrm{b}}$ & E. cypellocarpa & New South Wales \\
\hline \multirow[t]{6}{*}{ M. grandis } & $\mathrm{AC} 165^{\mathrm{g}, \mathrm{h}}$ & E. saligna & Victoria \\
\hline & I00206 & E. globulus & Victoria \\
\hline & I00219b & E. globulus & Victoria \\
\hline & $\mathrm{S} / 1 / 2 / 3^{\mathrm{e}}$ & E. globulus/nitens & Tasmania \\
\hline & $\mathrm{Q} / 1 / 1 / 1^{\mathrm{e}}$ & E. nitens & Tasmania \\
\hline & $\mathrm{H} / 1 / 3 / 1^{\mathrm{e}}$ & E. nitens & Tasmania \\
\hline \multirow[t]{8}{*}{ M. nubilosa } & $\mathrm{AC} 106^{\mathrm{g}, \mathrm{h}}$ & E. globulus & Victoria \\
\hline & $\mathrm{L} / 1 / 2$ multispore $^{\mathrm{e}}$ & Not recorded & Victoria \\
\hline & StMarys $/ 2 / 4^{\mathrm{e}}$ & E. globulus & Tasmania \\
\hline & StMarys $/ 2 / 8^{e}$ & E. globulus & Tasmania \\
\hline & $\mathrm{Z} / 1 / 1 / 11^{\mathrm{e}}$ & E. globulus & Tasmania \\
\hline & E1 multispore ${ }^{\mathrm{e}}$ & E. globulus & Tasmania \\
\hline & $\mathrm{Z} / 1 / 1 / 13^{\mathrm{e}}$ & E. globulus & Tasmania \\
\hline & $\mathrm{S} / 2 / 1 / 1^{\mathrm{e}}$ & E. globulus & Tasmania \\
\hline M. parkii & CBS $387.92^{\mathrm{c}, \mathrm{d}}$ & E. grandis & Brazil \\
\hline \multirow[t]{4}{*}{ M. parva } & $\mathrm{AC} 83^{\mathrm{g}, \mathrm{h}}$ & E. globulus & Victoria \\
\hline & $\mathrm{AC} 85^{\mathrm{g}, \mathrm{h}}$ & E. globulus & Victoria \\
\hline & AC89g,h & E. globulus & Victoria \\
\hline & CBS $110503^{c}$ & E. globulus & Western Australia \\
\hline M. pini & $\mathrm{DT}^{\mathrm{b}}$ & Pinus radiata & New South Wales \\
\hline M. suberosa & CBS $436.92^{c}$ & E. dunnii & Brazil \\
\hline \multirow[t]{2}{*}{ Mycosphaerella sp. 1 (received as $M$. parkii) } & CBS $208.94^{c}$ & E. grandis & Indonesia \\
\hline & CBS $209.94^{c}$ & E. grandis & Indonesia \\
\hline Mycosphaerella sp. 2 (received as $M$. parkii) & CBS516.93 & E. globulus & Brazil \\
\hline \multirow[t]{3}{*}{ M. tasmaniensis } & I555 & Not recorded & Tasmania \\
\hline & $\mathrm{BS} 10 / 2^{\mathrm{e}, \mathrm{h}}$ & E. nitens & Tasmania \\
\hline & $\mathrm{S} / 3 / 2 / 7^{\mathrm{e}, \mathrm{h}}$ & E. globulus/nitens & Tasmania \\
\hline \multirow[t]{5}{*}{ M. vespa } & $\mathrm{A} / 1 / 3^{\mathrm{e}}$ & E. globulus & Tasmania \\
\hline & $\mathrm{B} / 3 / 2 / 1^{\mathrm{e}}$ & E. globulus & Tasmania \\
\hline & $\mathrm{A} / 1 / 7^{\mathrm{e}}$ & E. globulus & Tasmania \\
\hline & $\mathrm{B} / 3 / 2 / 4^{\mathrm{e}}$ & E. globulus & Tasmania \\
\hline & BrunyIs $/ 1 / 1^{\mathrm{e}}$ & E. globulus & Tasmania \\
\hline \multirow[t]{3}{*}{ Phaeophleospora eucalypti } & $\mathrm{NZFS} 85 \mathrm{C} / 1^{\mathrm{i}}$ & E. nitens & New Zealand \\
\hline & NZFS85C/3i & E. nitens & New Zealand \\
\hline & $\mathrm{NZFS} 85 \mathrm{C} / 23^{\mathrm{i}}$ & E. nitens & New Zealand \\
\hline Quambalaria cyanescens & IMI178848j & E. pauciflora & New South Wales \\
\hline Q. eucalypti & $\mathrm{S} 8^{\mathrm{k}}$ & E. globulus (bark) & Uruguay \\
\hline$Q$. pitereka & E7440 ${ }^{\mathrm{f}}$ & Corymbia maculata & Western Australia \\
\hline
\end{tabular}

a Superscripts identify culture source.

b CSIRO FFP Canberra.

c Centraal Bureau voor Schimmelcultures.

d Type strain.

e University of Tasmania.

f CSIRO FFP Perth.

g Angus Carnegie, LaTrobe University.

h DNA was extracted from an old, nongrowing culture.

i New Zealand Forest Research.

j International Mycological Institute.

k University Viçosa, Brazil. 
Sampling of leaf material from plantations and forest regrowth sites. A survey of 2-year-old E. globulus was conducted at Smithton in northwestern Tasmania on 8 August 2003 $\left(\mathrm{S} 40^{\circ} 55^{\prime} 21^{\prime \prime}, \mathrm{E} 144^{\circ} 59^{\prime} 39^{\prime \prime}\right)$. The plantation of approximately 21 ha was divided into six sections and 10 leaf samples were taken from separate trees in each section. Juvenile leaves were sampled from branches at a height of $1.2 \mathrm{~m}$ from trees that were up to $4 \mathrm{~m}$ tall. These trees were selected using systematic sampling starting from the first two trees, moving over a row and sampling the next two trees, and so on, until the required number of samples was taken. Leaves were taken from the fourth to fifth leaf pair on each branch to minimize variation in leaf age, physiological development, height in the canopy, and age of the lesions. Lesions from lateral branch stems also were sampled from seven randomly selected E. globulus trees in the same trial.

Additional samples for confirmation that the test was applicable to other host species were collected at four different sites in north and northeastern of Tasmania. In all, 16 E. nitens samples were taken from plantations at Weldborough (S41 $13^{\prime} 14^{\prime \prime}$, E147 $\left.51^{\prime} 60^{\prime \prime}\right)$, St. Helens (S41 ${ }^{\circ} 20^{\prime} 41^{\prime \prime}$, E148 $3^{\prime} 55^{\prime \prime}$ ), and Scottsdale (S41 $\left.15^{\prime} 34^{\prime \prime}, \mathrm{E} 147^{\circ} 25^{\prime} 25^{\prime \prime}\right)$. Leaf material was sampled from branches at a height of $1.2 \mathrm{~m}$ and sampled from the fourth to fifth pair on each branch from trees $\approx 5$ to $6 \mathrm{~m}$ tall, selected using a systematic sampling regime as described above. A collection of four samples was made from natural forest regeneration of E. regnans at a roadside site near Bicheno (S41 $48^{\prime} 19^{\prime \prime}$, E148 $\left.14^{\prime} 53^{\prime \prime}\right)$. Leaves were taken from the fourth pair on branches. Trees were $\approx 1.5 \mathrm{~m}$ tall and $\approx 12$ months old.

Lesions were excised with a scalpel, using a fresh blade for each sample to avoid DNA cross-contamination. Each sample was $1 \mathrm{~cm}^{2}$ and consisted of up to 15 lesions per leaf, pooled. The stem samples from E. globulus were obtained by scraping the surface of stem lesions with a scalpel to produce shavings and approximately $80 \mathrm{~mm}^{2}$ of stem surface area was taken.

DNA extraction, PCR, and sequencing. Plant material and fungal mycelium were ground in $1.5-\mathrm{ml}$ microfuge tubes with a pellet pestle mixer (in liquid nitrogen for leaf and stem samples), mixed with extraction buffer (65), and incubated for $1 \mathrm{~h}$ at $65^{\circ} \mathrm{C}$. Tubes were centrifuged at $14,000 \mathrm{rpm}$ for $15 \mathrm{~min}$ and the supernatant removed. Purification was achieved by binding to a silica matrix in the presence of NaI (31). PCR was carried out in an Applied Biosystems (Foster City, CA) GeneAmp PCR System 2700 thermocycler. Reactions of $25 \mu \mathrm{l}$ contained $0.55 \mathrm{U}$ of TTH+ Polymerase (Fisher Biotec, Subiaco, Western Australia) in $1 \times$ polymerization buffer (Fisher Biotec), $2.0 \mathrm{mM} \mathrm{MgCl}_{2}$, bovine serum albumen at $0.2 \mathrm{mg} / \mathrm{ml}, 0.2 \mathrm{mM}$ each dNTP, and $0.25 \mu \mathrm{M}$ each primer. For sequencing, the entire ITS1, 5.8S, and ITS2 regions were amplified using primers ITS1-F (29) and ITS4 (76) and the following thermocycler program: $94^{\circ} \mathrm{C}$ for $3 \mathrm{~min} ; 35$ cycles of $94^{\circ} \mathrm{C}$ for $30 \mathrm{~s}, 55^{\circ} \mathrm{C}$ for $30 \mathrm{~s}$, and $72^{\circ} \mathrm{C}$ for $30 \mathrm{~s}$; followed by an extension step of $72^{\circ} \mathrm{C}$ for $7 \mathrm{~min}$. PCR products were electrophoresed on a $1 \%$ agarose (Fisher Biotec) gel at $4 \mathrm{~V} / \mathrm{cm}$ for $1 \mathrm{~h}$. Before sequencing, PCR products were purified with an UltraClean PCR Clean-up DNA purification kit (MoBio Laboratories, Inc., West Carlsbad, CA). Sequences were determined with an ABI Prism Dye Terminator Cycle Sequencing kit on a Bio-Rad 373 Sequencer (Hercules, CA) with stretch upgrade. Sequences were obtained in both directions and assembled with Lasergene software (DNAStar, Madison, WI).

Phylogenetic analysis and primer design. Sequences generated in this project are listed in Table 2. Further sequences were retrieved from GenBank and EMBL. Mycosphaerella and anamorph species included in the analysis were selected on the basis of (i) occurrence on members of Myrtaceae or (ii) high sequence similarity to a species from Myrtaceae. All available sequence variants for each species were included with the exception of two related anamorph groups (Cercospora and Trimmatostroma), with sequence similarity of $<85 \%$ to any of the target species and which previously have been shown to form distinct clusters in phylogenetic analyses (20,33). Hortaea werneckii was included on the basis of high sequence similarity, but only one ITS sequence was selected from the 17 available at the time. Alignments were performed with CLUSTALW (73) and adjusted manually. Phylogenetic analyses were executed with DNAPars and DNAML of the PHYLIP package (26) on the Australian National Genome Information Service (ANGIS, Sydney, NSW, Australia). Initial analysis was by DNAPars, with Phaeoramularia hachijoensis (AY251086) set as the outgroup, jumbling 10 times, and all other options as default. The set of most parsimonious trees were subjected to maximum likelihood analysis by DNAML with Phaeoramularia hachijoensis (AY251086) set as the outgroup, global rearrangements on, and all other options as default. The sequence alignment and phylogenetic tree were deposited in TreeBase (accession number TBA). Primers were designed following the general concepts outlined by Dieffenbach (24), with two additional aims. To permit future multiplexing of the five specific PCRs, primer sites were selected to produce amplicons of different size for each species and primer lengths were modified to result in the same annealing temperature for all primers. BLAST searches of GenBank and EMBL also were carried out using the taxon-specific primer sequences.

Primer specificity testing. Primers were tested for specificity on a broad range of template DNA, including pure cultures of Mycosphaerella spp., other eucalypt leaf pathogens (Table 1), and clean eucalyptus leaves. To obtain optimum specificity and efficiency of amplification, several different annealing temperatures were tested. Primer lengths were adjusted by 1 or 2 bases until all primer pairs amplified the target species or group at the same annealing temperature, with no amplification from other species.

Construction of an IAC for first-round PCR. A plasmid containing primer-binding sites for the primers ITS1-F (29), ITS5, and ITS4 (76) was constructed by ligation of a histone gene fragment amplified from Phaeophleospora eucalypti DNA using composite primers (Table 3 ). The forward primer sequence is a composite of ITS1-F, ITS5, and H3-1a (32), with H3-1a at the 3' end, and the reverse a composite of ITS4 and H3-1b (32), with $\mathrm{H} 3-1 \mathrm{~b}$ at the $3^{\prime}$ end. A product of $\approx 1,100 \mathrm{bp}$ was amplified using conditions for the $\mathrm{H} 3-1 \mathrm{a} / \mathrm{H} 3-1 \mathrm{~b}$ primers (32). This product was purified with an UltraClean PCR Clean-up DNA purification kit (MoBio Laboratories, Inc.) and transformed into Escherichia coli using a pGEM-T cloning kit (Promega Corp. Madison, WI). Plasmid DNA was extracted using an Ultraclean plasmid extraction kit (MoBio Laboratories, Inc.).

Nested PCR. All reactions were set up in UV-irradiated laminar flow hoods with positive (DNA from pure culture of target species) and negative (DNA from pure cultures of nontarget species and no added template) controls included in each set of reactions. Aerosol barrier tips were used routinely and gloves

TABLE 2. Sequences generated in this project for primer design and species verification

\begin{tabular}{|c|c|}
\hline Species & Accession numbers \\
\hline Mycosphaerella africana & AY626981 \\
\hline M. cryptica & AY667576, AY626989, DQ471928 \\
\hline M. grandis & AY626986 \\
\hline M. nubilosa & AY667577, DQ471926 \\
\hline M. parkii & AY626979 (type isolate) \\
\hline M. parva & AY626980 \\
\hline Mycosphaerella sp. 1 & AY66982, AY626983 \\
\hline Mycosphaerella sp. 2 & AY626984 \\
\hline M. suberosa & AY626985 \\
\hline M. tasmaniensis & AY667578 (type isolate) \\
\hline M. vespa & DQ471925, DQ471927 \\
\hline Phaeophleospora eucalypti & AY626987, AY626988 \\
\hline
\end{tabular}


were always worn and changed frequently to minimize crosscontamination. First-round PCR used primers ITS1-F and ITS4 as outlined above, with the addition of $25 \mathrm{fg}$ of IAC in each $25-\mu \mathrm{l}$ reaction. Failure of first-round amplification (as occurred in a few leaf samples) demonstrated the need to repeat the first-round PCR using a more dilute sample. First-round product was diluted 1/10 and a 5- $\mu \mathrm{l}$ aliquot was used as template in a $25-\mu \mathrm{l}$ nested PCR reaction with species-specific primers. Concentrations were $0.25 \mu \mathrm{M}$ for each primer, $2 \mathrm{mM} \mathrm{MgCl}_{2}$, and $0.2 \mathrm{mM}$ each $\mathrm{dNTP}$ in $1 \times$ polymerization buffer (Fisher Biotec), with $0.55 \mathrm{U}$ of TTH+ polymerase (Fisher Biotec) per $25-\mu$ l reaction.

Cloning and sequencing of PCR products from multiple fungal species in leaf samples. Independent confirmation of PCR test results by isolation of corresponding species from the same leaf samples was not possible because not all samples had pseudothecia and not all samples with pseudothecia had mature spores. Therefore, confirmation was sought by amplification, cloning, and sequencing of fungal PCR products from selected leaf samples. Fungal ITS products were amplified with ascomycetespecific primer combination ITS1-F (29) and ITS4-A (46) using the same reagent concentrations and thermocycler program as given above for ITS1-F/ITS4. Products were purified with an UltraClean PCR Clean-up DNA purification kit (MoBio Laboratories, Inc.) and cloned using a pGEM-T cloning kit (Promega Corp.). These primers had not been used previously in the laboratory and amplified a larger fragment than any primers used previously, so that the possibility of chance contamination with PCR product was eliminated. Individual clones were tested with the species-specific primers, and a representative of each species from each leaf sample was sequenced using primers ITS1-F and ITS4 as described previously.

Plantation survey. Every set of PCR reactions included five samples containing DNA from cultures of each of the five species or taxa groups and one sample with no template DNA. The four nontarget species in each of the species-specific tests were treated as additional negative controls. The test was repeated on $\approx 30 \%$ of samples to demonstrate the consistency of the analysis. Although the ITS primers for $M$. vespa also are able to detect $M$. ambiphylla and $M$. molleriana, these species previously have not been recorded in Tasmania, whereas $M$. vespa has been recorded over the majority of the state (51). For simplicity, the positive results for this group are referred to as $M$. vespa. The possibility of M. molleriana and M. ambiphylla occurring in Tasmania has not been eliminated.

\section{RESULTS}

Phylogenetic analysis and primer design. A phylogenetic analysis of ITS sequences was carried out after sequence alignment to accommodate the following points: (i) intraspecific variation in ITS sequences of some Mycosphaerella spp., (ii) a degree of taxonomic uncertainty for some species, and (iii) quality control for sequences obtained from public databases (the accuracy and reliability of which was beyond our control). Phylogenetic analysis showed species with ITS sequences most similar to the target species to facilitate the selection of interspecific divergent regions most suitable for species-specific primer design. Phylogenetic analysis also assisted in the detection of misidentified species from public sequence databases or culture collections.

In all, 165 nonredundant ITS sequences from 95 Mycosphaerella and related anamorph species that were obtained from GenBank or produced here were included in the phylogenetic analysis (Fig. 1). All available sequences of Mycosphaerella spp. that occur on Eucalyptus spp. were included in the analysis, as were several species from other hosts. Species known from eucalypts for which ITS sequences were not available include $M$. delegatensis, $M$. endophytica, $M$. gracilis, $M$. longibasalis, and $M$. swartii. Sequences AY045519 (M. suttoniae) and AY626984 (Mycosphaerella sp.) had segments of 157 and $181 \mathrm{bp}$, respectively, removed from ITS1 after the initial alignment revealed that these were most probably insertions. The insertions were at different sites and did not appear to be homologous. Analysis by DNAPARS produced 428 equally most parsimonious trees of 3,170 steps. DNAML analysis of this set produced an ML tree with an Ln likelihood = $-13,649.6$.

For each of the five target species (M. cryptica, M. nubilosa, $M$. vespa, $M$. grandis, and $M$. tasmaniensis), variable regions were visually selected from the alignment of 95 Mycosphaerella spp. Particular attention was paid to discriminating species that had high overall sequence similarity and that clustered closely in the ML tree. The variable regions anchored the $3^{\prime}$ end of speciesspecific primers and primer length was varied at the $5^{\prime}$ end to give similar annealing temperatures. Species-specific primers were designed for $M$. cryptica, M. nubilosa, and M. tasmaniensis. High interspecific sequence similarity combined with intraspecific variation prevented the design of species-specific primers for $M$. vespa and $M$. grandis. Therefore, primers were designed for two taxa groups: one primer pair for $M$. vespa, M. ambiphylla, and M. molleriana, and one primer pair for M. grandis and M. parva. Regions were chosen to give a different product size for each species with a view to future multiplexing of the tests. Primer sequences were checked for self-annealing and BLAST search results were checked to ensure that only the target species matched both primers. Primer sequences and expected product sizes are given in Table 3.

Arrows on branches indicate groups that have an exact match to primer sequences (Fig. 1). Each of these branches is supported by 99\% confidence limits. This includes all available sequences for each target taxon, with two exceptions: AF173307 was very different from all other M. tasmaniensis sequences, grouping instead with Mycovellosiella eucalypti and Phaeoramularia saururi, and AY534227 grouped with the other M. vespa sequences but dif-

TABLE 3. Species-specific primers designed from Mycosphaerella spp. internal transcribed spacer (ITS) sequences and composite primers used to construct an internal amplification control for ITS1-F/ITS4 and ITS5/ITS4 PCR

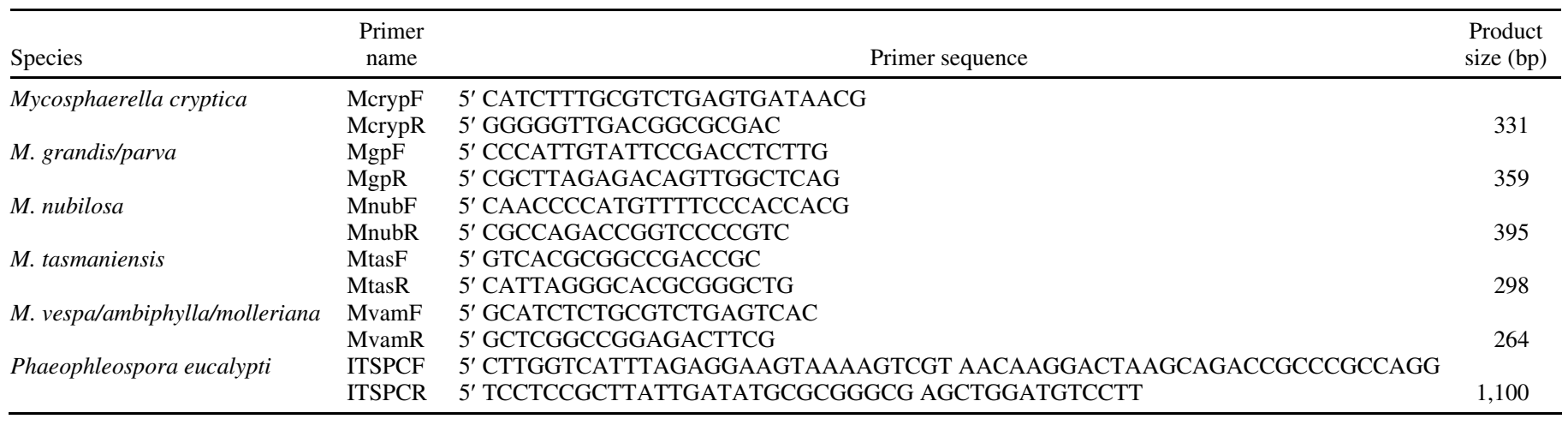




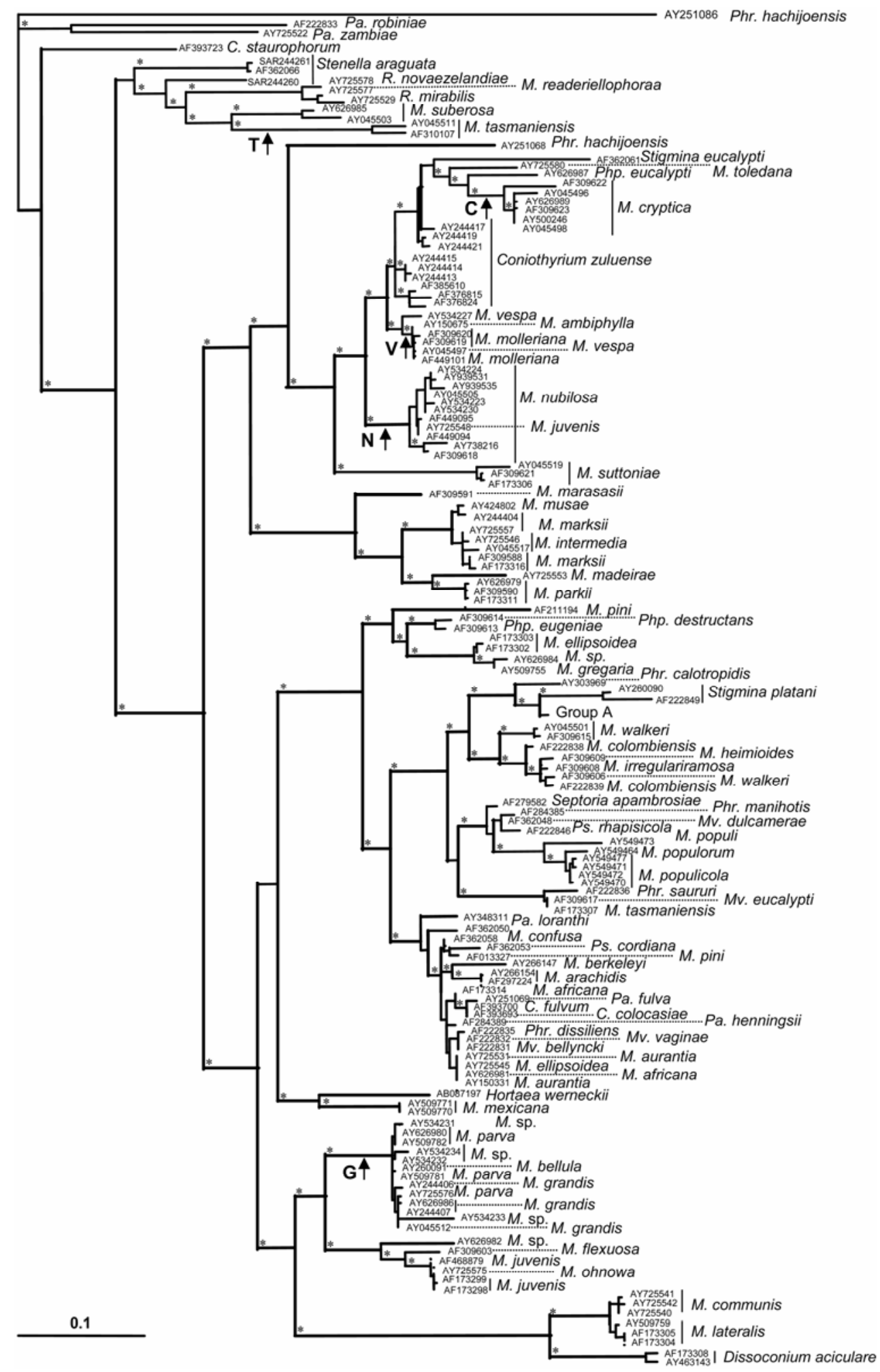

Fig. 1. Maximum likelihood tree produced by phylogenetic analysis of 165 internal transcribed spacer sequences from Mycosphaerella and related anamorph species, Ln likelihood $=-13,649.6$. The outgroup is Phaeoramularia hachijoensis and the scale bar represents expected nucleotide variation of $10 \%$. Clades that are supported with $99 \%$ confidence are denoted by an asterisk above the branch. Arrows on branches represent the groups that have $100 \%$ similarity to the taxonspecific primer sequences as follows: G, Mycosphaerella grandis/parva group; V, M. vespa/ambiphylla/molleriana group; N, M. nubilosa; C, M. cryptica; and T, M. tasmaniensis. Abbreviations for genera are: M., Mycosphaerella and the anamorph genera C., Cladosporium; Mv., Mycovellosiella; Pa., Passalora; Php., Phaeophleospora; Phr., Phaeoramularia; Ps., Pseudocercospora; and R., Readeriella. The anamorph genera are those given in the GenBank accessions, although many of them recently have been recombined $(5,6,15)$, appropriate formal name changes have not been made by the sequence submitters. In addition, some sequences listed in GenBank as belonging to M. juvenis and M. ellipsoidea are included as belonging to those species, though the isolates that were sequenced probably represent different taxa (P. W. Crous, perssonal communication). To improve readability of the tree, one branch, distant from the target taxa, has been pruned. Group A represents two Mycosphaerella spp., M. fori and M. musicola, and 14 Pseudocercospora spp.: P. basiramifera, P. cordiana, P. cruenta, P. eriodendri, P. eucalyptorum, P. hibbertiaeasperae, P. luzardi, P. macrospora, P. natalensis, P. paraguayensis, P. platyloba, P. pseudoeucalyptorum, P. robusta, and $P$. syzygicola. These are included in the tree submitted to Treebase. 
fered by $2.3 \%$ and had two mismatches to the forward primer for Mycosphaerella vespa/ambiphylla/molleriana.

By contrast, $M$. ambiphylla and $M$. molleriana sequences grouped closely with the remaining $M$. vespa sequences with $99 \%$ confidence and had a $100 \%$ match to the M. vespa primers. Percent difference among this group was only 0.2 to $1.0 \%$. In addition, sequences for $M$. grandis and $M$. parva were very similar to each other $(99.2 \%)$ and form a single clade with high support. Furthermore M. bellula, derived from a Proteaceae family host, and other unnamed isolates from eucalypts also fall within this clade and all have a $100 \%$ match to the $M$. grandis/parva primers.

IAC for first-round PCR. Plasmid p35.12 was selected for use as an IAC because it had an insert of the correct size $(\approx 1,100 \mathrm{bp})$ that was amplifiable with the ITS1-F and ITS4 primers. A PCR product was visible when 2.5 fg of IAC was the only DNA template added to a $25-\mu$ l reaction (Fig. 2); however, addition of leaf or fungal DNA required a higher concentration of IAC (Fig. 3). Therefore $25 \mathrm{fg}$ was added to each $25-\mu \mathrm{l} \mathrm{PCR}$, which equates to $6 \times 10^{4}$ copies per reaction. Successful first-round amplification with ITS1-F and ITS4 primers verified that the template DNA from plant material or fungal cultures was amplifiable, even if fungal DNA was at too low a concentration to be detected after one round of PCR. This increased confidence that subsequent negative results for taxon-specific primers were not false negatives caused by PCR inhibition. If fungal DNA was present at a much higher concentration, amplification of IAC was prevented by competition. Thus, a visible product from either the IAC or fungal DNA or, in some cases, both, indicated successful firstround PCR.

Specificity, sensitivity, and reliability testing of primer sets. Species-specific primers $(0.25 \mu \mathrm{M})$ were used in the secondround amplification of a nested PCR after first-round amplification with ITS1-F and ITS4. After specificity testing of all primer pairs at several annealing temperatures, the optimum thermocycler program to run the species-specific primers simul-

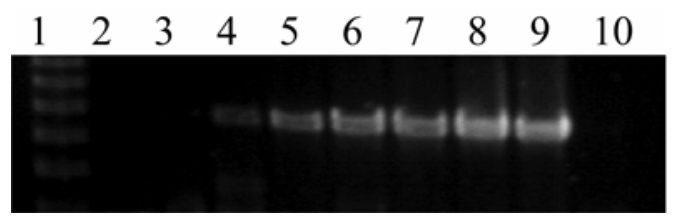

Fig. 2. Evaluation of sensitivity of amplification of the internal amplification control plasmid (IAC) using primers ITS1-F/ITS4. Lane 1 contains a 200-bp ladder showing fragments of 600 to $1,600 \mathrm{bp}$ and lane 10 is no template control. Template concentrations are lane $2,10^{-18} \mathrm{~g} / \mu \mathrm{l}$ or 60 copies per $25-\mu \mathrm{l}$ reaction; lane $3,10^{-17} \mathrm{~g} / \mu \mathrm{l}$ or 600 copies; lane $4,10^{-16} \mathrm{~g} / \mu \mathrm{l}$ or 6,000 copies; lane $5,1 \mathrm{fg} / \mu \mathrm{l}$ or $6 \times 10^{4}$ copies; lane $6,10 \mathrm{fg} / \mu \mathrm{l}$ or $6 \times 10^{5}$ copies; lane 7 , $100 \mathrm{fg} / \mu \mathrm{l}$ or $6 \times 10^{6}$ copies; lane $8,1 \mathrm{pg} / \mu \mathrm{l}$ or $6 \times 10^{7}$ copies; and lane $9,10 \mathrm{pg}$ or $6 \times 10^{8}$ copies.

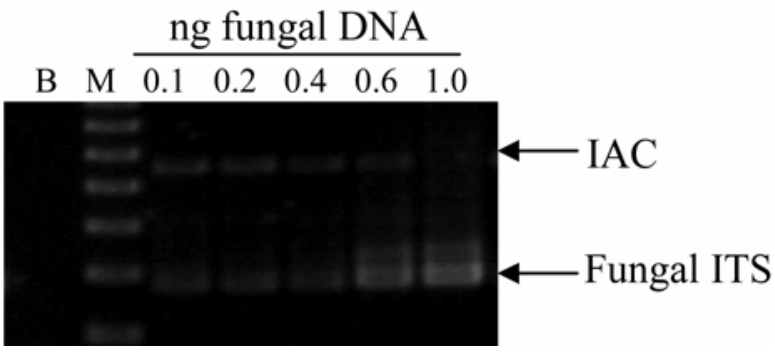

Fig. 3. Sensitivity of amplification of fungal DNA with primers ITS1-F and ITS4 with the addition of $25 \mathrm{fg}$ of internal amplification control plasmid (IAC) to each $25-\mu 1$ polymerase chain reaction. Lane $M$ contains a 200-bp ladder showing fragments of 400 to $1,400 \mathrm{bp}$. Amplification of the IAC is competitively inhibited at the higher fungal DNA concentrations. taneously was $94^{\circ} \mathrm{C}$ for $3 \mathrm{~min} ; 20$ cycles of $94^{\circ} \mathrm{C}$ for $30 \mathrm{~s}, 62^{\circ} \mathrm{C}$ for $30 \mathrm{~s}$, and $72^{\circ} \mathrm{C}$ for $30 \mathrm{~s}$; followed by $72^{\circ} \mathrm{C}$ for $10 \mathrm{~min}$.

Each individual primer pair, designed to detect Mycosphaerella spp. or closely related species groups from plantation Eucalyptus spp., were highly specific for their respective targets (Fig. 4B to F). The specific primer pairs verified the taxa of 3 to 15 isolates of each of the target species from culture collections (Table 4). These tests were done in a series of experiments with replication of randomly chosen standard isolates and had identical results, showing the reliability of the test. In double-blind trials, the primers unequivocally discriminated among the five species or taxon groups and did not detect cultures of nontarget species, including possible co-occurring fungal pathogens, verifying their reliability (Table 4; Fig. 4B to F). With nested PCR, each primer pair was sensitive enough to detect pathogen DNA when present at concentrations of 10 to $100 \mathrm{fg}$ per $25-\mu \mathrm{l}$ reaction (Fig. 5). Amplification at these low levels of template DNA was not reliable in repeated trials and this may be attributed to stochastic events involving target sequences at such low concentrations. Amplification from $10 \mathrm{fg}$ of $M$. grandis DNA with no amplification from $100 \mathrm{fg}$ (Fig. 5B and C) supports this hypothesis. The addition of plant DNA to the first-round PCR, equivalent to that in a commonly used dilution of the averagesized leaf sample, appeared to reduce final sensitivity by a factor of $\approx 10$ (Fig. 5B). Addition of IAC appeared to have the reverse effect, though this also may have been a result of stochastic effects.

In 2 days in a double-blind trial, one person using the detection test successfully differentiated the appropriate species (M. cryptica, $M$. grandis/parva, $M$. nubilosa, and Mycosphaerella sp. nov.) (Table 1; data not shown) from 30 cultures from disease surveys in Eucalyptus plantations that had been identified at the time of isolation according to the taxonomic criteria available at that time. The PCR detection test results were verified by subsequent sequencing of the complete ITS regions of these isolates (Table 2; data not shown).

Testing of primers on plant material. The primers successfully detected Mycosphaerella spp. directly from infected leaves and stems (Fig. 6). At least one, and up to four, Mycosphaerella spp. were detected from each leaf or stem sample. The robustness of the detection systems to test for Mycosphaerella spp. in a wide range of tissue types was further indicated by amplification of specific products from dead, dried, herbarium collections. The nested PCR reactions enabled detection and discrimination of the five Mycosphaerella taxa in 30 samples with lesions at any developmental stage by one person within 2 days.

Verification of infection with multiple Mycosphaerella spp. by cloning of PCR products. Isolation of Mycosphaerella spp. from leaf lesions does not produce cultures of nonsporulating species; therefore, infection by multiple Mycosphaerella spp. was verified by cloning PCR products from selected leaf samples, then testing individual clones by species-specific PCR and sequencing. A comparison of species detected by taxon-specific nested PCR with those detected by cloning and sequencing (Table 5) shows that, although fewer species were detected by the latter method, the presence of multiple species in individual leaves or even individual lesions was confirmed. One leaf sample that had given a negative result for all the taxon-specific nested PCRs produced a clone containing an M. grandis sequence (Table 5, sample 3). Other species of possible leaf pathogens also were detected by the cloning method (data not shown). No clones containing $M$. vespa or $M$. tasmaniensis sequences were detected, even though five and two samples, respectively, had tested positive to these species by nested PCR. To verify that the nested PCR product was amplified from these two species and not from an untested fungus present in the leaf sample, the taxon-specific amplicons were sequenced. The sequences were 99 to $100 \%$ identical to published sequences from $M$. vespa and $M$. tasmaniensis, though single nucleotide polymorphisms occurred among the $M$. vespa sequences from different geographic areas (Table 5). 
Plantation survey. Most leaves contained more than one lesion and, therefore, most $1-\mathrm{cm}^{2}$ samples consisted of subsamples from more than one lesion. No relationship was observed between the number of lesions sampled per leaf and the number of species detected. Leaves from both E. nitens and E. globulus with only one lesion contained two to three Mycosphaerella spp. (Fig. 6).

The Mycosphaerella spp. most frequently detected on E. globulus were M. cryptica, M. nubilosa, and M. grandis/parva
(Table 6). All E. nitens, E. globulus, and E. regnans leaves from the plantation survey contained multiple Mycosphaerella spp., with three or more species occurring on most leaves (Table 7). The analysis for $30 \%$ of samples was repeated independently and produced consistent results. All leaf and stem lesions were analyzed at an early developmental stage. E. globulus leaves contained $M$. cryptica, M. grandis/parva, and either $M$. vespa, M. tasmaniensis, or M. nubilosa (Table 7), including several

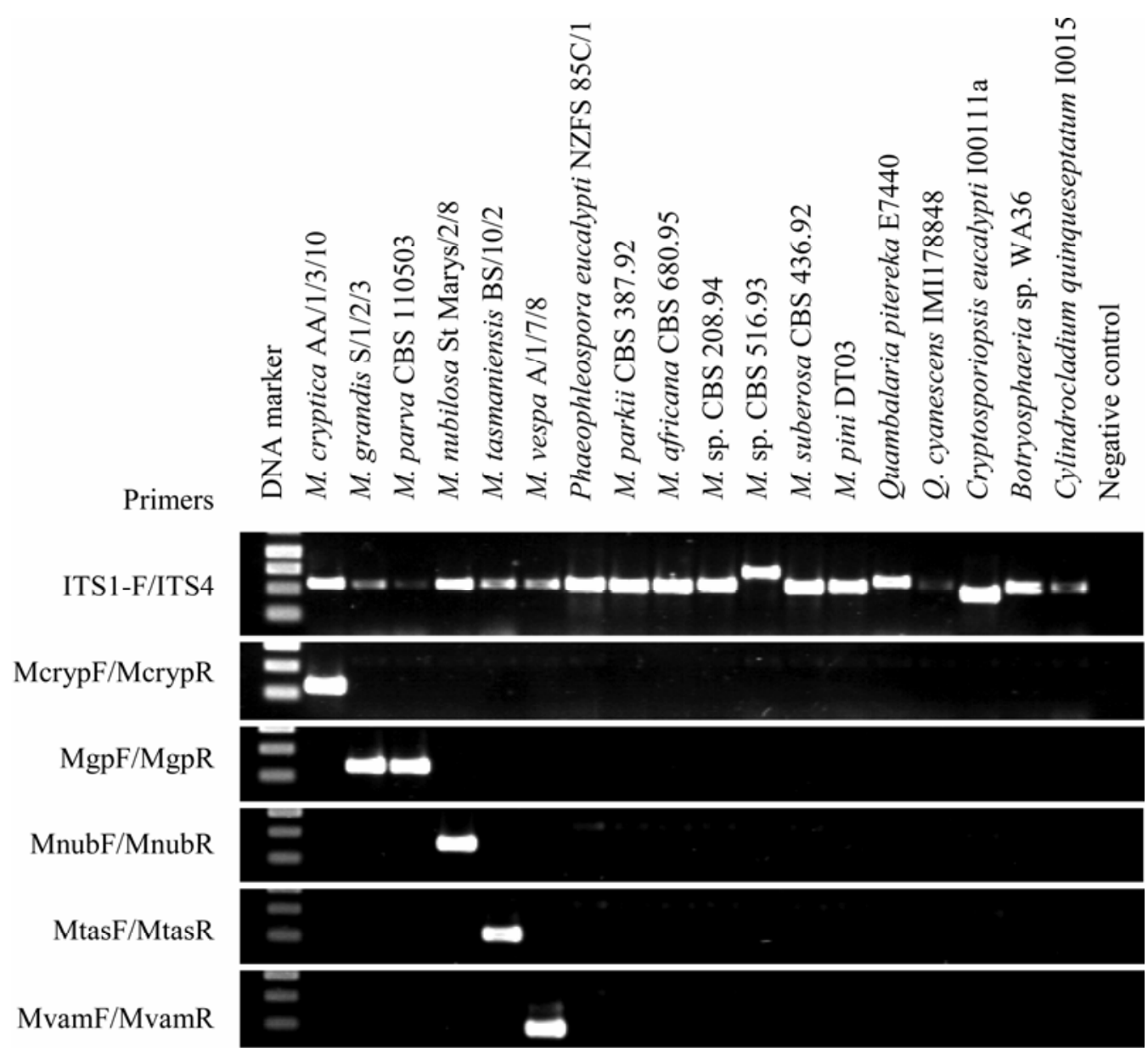

Fig. 4. Specificity of each pair of species-specific primers: polymerase chain reaction products from first-round amplification with primers ITS1-F/ITS4 and second-round amplification with specific primers.

TABLE 4. Results of taxon-specific nested polymerase chain reaction detection tests for the five Mycosphaerella $\operatorname{taxa}^{\mathrm{a}}$

\begin{tabular}{|c|c|c|c|c|c|}
\hline Species (no. of isolates tested) & $\mathrm{C}$ & G & $\mathrm{N}$ & $\mathrm{T}$ & $\mathrm{V}$ \\
\hline Botryosphaeria sp. (1) & - & - & - & - & - \\
\hline Cylindrocladium retaudii (1) & - & - & - & - & - \\
\hline M. cryptica $(15)$ & + & - & - & - & - \\
\hline M. grandis (7) & - & + & - & - & - \\
\hline M. nubilosa (8) & - & - & + & - & - \\
\hline M. parkii (1) & - & - & - & - & - \\
\hline Mycosphaerella sp. 1 (3) & - & - & - & - & - \\
\hline Mycosphaerella suberosa (1) & - & - & - & - & - \\
\hline M. tasmaniensis (3) & - & - & - & + & - \\
\hline M. vespa $(5)$ & - & - & - & - & + \\
\hline Phaeophleospora eucalypti (3) & - & - & - & - & - \\
\hline Quambalaria cyanescens (1) & - & - & - & - & - \\
\hline Q. eucalypti (2) & - & - & - & - & - \\
\hline
\end{tabular}

${ }^{a}$ Columns $\mathrm{C}, \mathrm{G}, \mathrm{N}, \mathrm{T}$, and V represent results for taxon-specific tests for $M$. cryptica, the $M$. grandis/parva group, M. nubilosa, M. tasmaniensis, and the M. vespa/ambiphylla/molleriana group, respectively. 
leaves with a single lesion. All stem samples contained $M$. grandis/parva, with two testing positive for only $M$. grandis/ parva. Five stem samples contained $M$. tasmaniensis and one had M. cryptica.

$M$. grandis/parva occurred on every leaf tested; however, it always occurred with either M. cryptica or M. nubilosa and often with $M$. tasmaniensis, M. vespa, or both. M. nubilosa was detected on one E. nitens sample. M. tasmaniensis was detected in $35 \%$ of E. globulus samples and $77 \%$ of E. nitens samples but was the only Mycosphaerella sp. absent from our samples of regrowth $E$. regnans. $M$. vespa occurred in $62 \%$ of $E$. globulus, $23 \%$ of $E$. nitens, and in samples from regrowth $E$. regnans.

The absence of false negatives due to PCR inhibition was demonstrated by amplification in first-round PCR, either of IAC or fungal ITS. Four samples that initially were negative for all species and the first-round amplification, gave positive results upon additional dilution of the DNA template (i.e., from 10- to 100-fold) for first-round PCR. Every positive was confirmed by lack of amplification in all of the negative controls. Samples from the various treatments and controls were processed randomly, and there was no evidence of cross contamination.

\section{DISCUSSION}

Five nested PCR detection tests were developed and their specificity verified against classically identified cultures of Mycosphaerella spp. and other genera pathogenic on Eucalyptus spp. The test identified cultures which had been given only a tentative identification during disease surveys and whose species relationship was confirmed by subsequent ITS sequence analysis. The sensitivity of all the nested PCR tests, at 10 to $100 \mathrm{fg}$ using DNA from pure cultures, with or without the addition of plant DNA (Fig. 5), approximates to an ascospore or hyphal cell with two to three nuclei, assuming a genome size of 10 to $100 \mathrm{Mbp}$. This is an important attribute, potentially enabling the detection tests to discriminate a few Mycosphaerella cells in leaf or stem samples or to identify cultures nondestructively sampled 7 to 14 days after they are initiated from germinated ascospores. The specificity of the primers is high under the stringent conditions of the tests because they have not amplified DNA from a wide range of related organisms. The probability of 18 to 24 nucleotide primers amplifying the DNA of an unrelated organism is $\approx 4^{-40}$ (equivalent to the probability of random occurrence of a 40-bp sequence, assuming that ITS sequences develop over a long period of time through a random process of unconstrained mutation and subsequent fixation), which is $<10^{-24}$.

The detection system distinguished among pathogens in culture and produced accurate, rapid diagnosis at an early stage of infection by five Mycosphaerella taxon groups, which is impossible

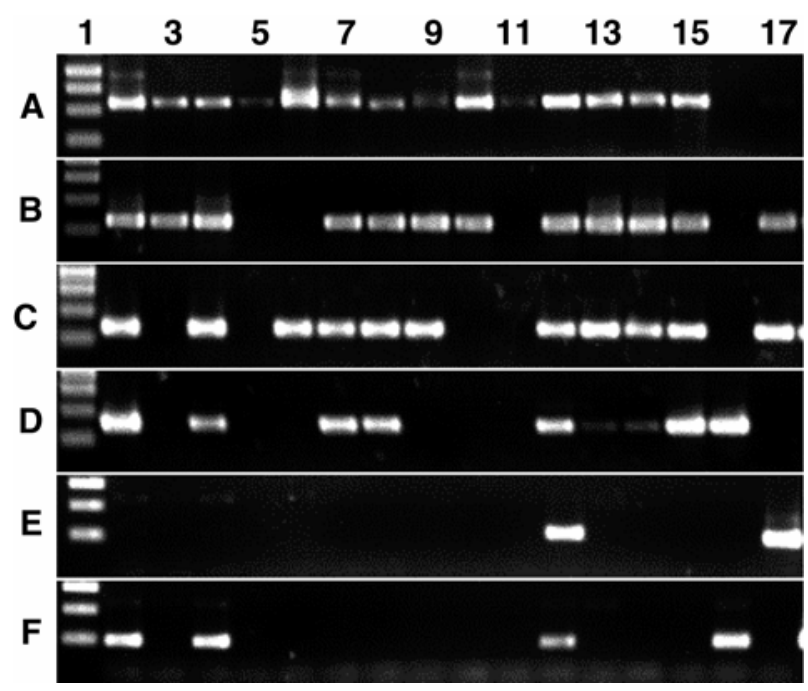

Fig. 6. Detection of Mycosphaerella spp. from leaf lesions. Polymerase chain reaction products from $\mathbf{A}$, first-round amplification with primers ITS1-F/ITS4 and $\mathbf{B}$ to $\mathbf{F}$, second-round amplification with specific primers. $\mathbf{B}, \mathrm{McrypF} /$ McrypR; C, MgpF/MgpR; D, MnubF/MnubR; E, MtasF/MtasR; and F, MvamF/MvamR. Lane 1, Promega 1-kb ladder showing fragments of 1,000 (A, C, and D only), 750, 500, and 250 bp; lane 2, E7417 Eucalyptus globulus, all lesions on leaf; lane 3, E7418 E. nitens, all lesions on leaf; lane 4, E7445, E. regnans, all lesions on leaf; lane 5, E. nitens, random sample, no disease evident; lanes 6 to 10, E. nitens, single leaf lesions at a range of developmental stages, from small purplish spots with no reproductive structures (lane 6) to large necrotic lesions with abundant pycnidia (lane 10); lane 11, E. globulus, random sample, no disease evident; lanes 12 to 16, E. globulus, single leaf lesion at a range of developmental stages, from small purplish spots with no reproductive structures (lane 12) to large necrotic lesions with abundant pycnidia (lane 16); lane 17, E. globulus, single stem lesion.

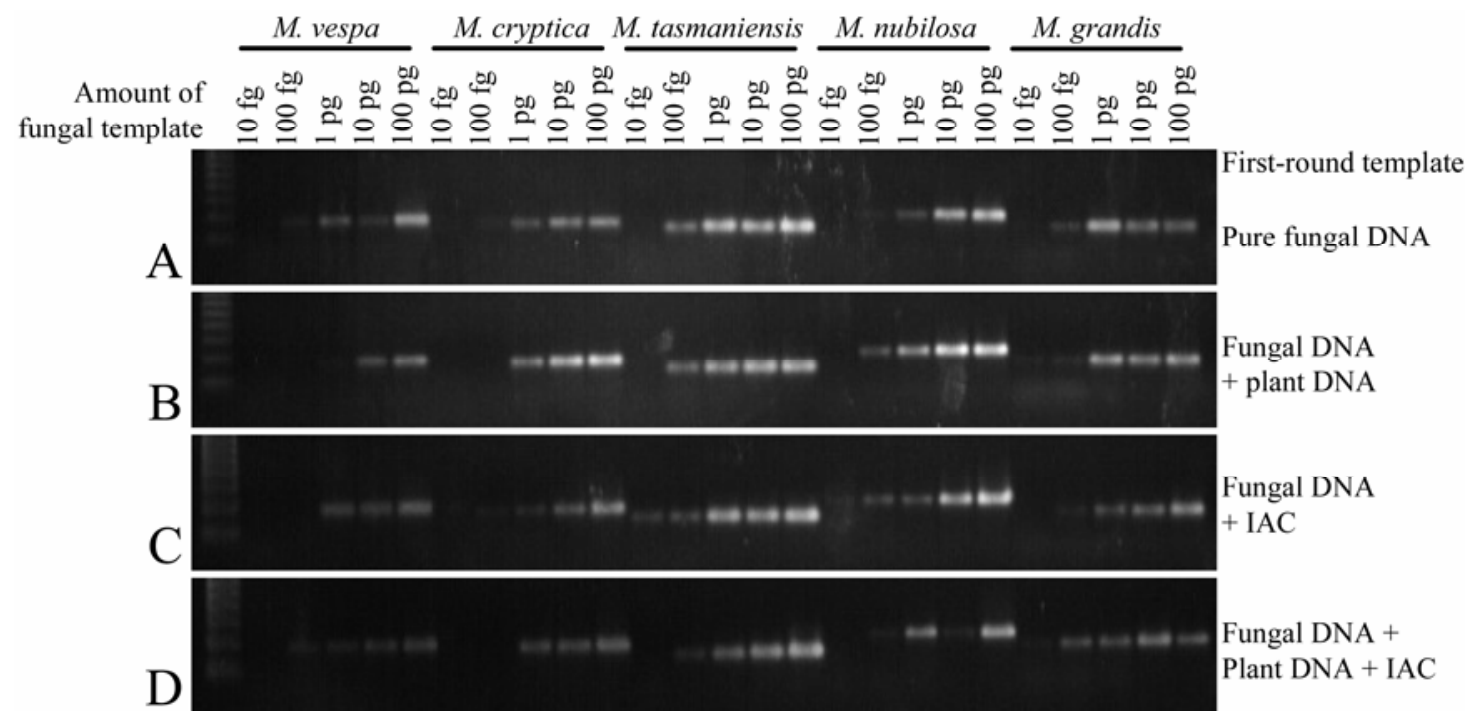

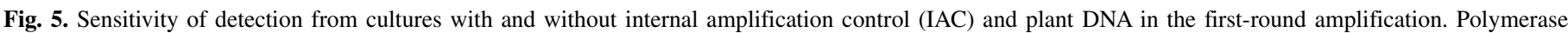

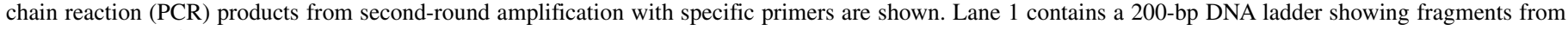

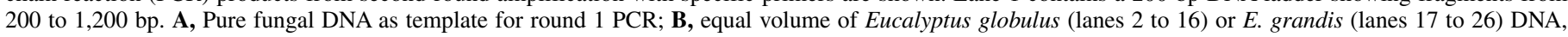

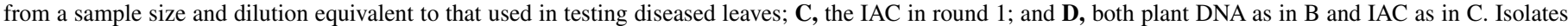

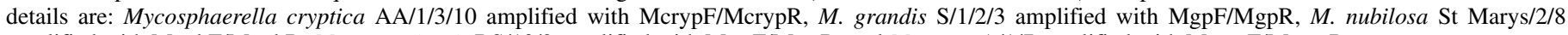
amplified with MnubF/MnubR, M. tasmaniensis BS/10/2 amplified with MtasF/MtasR, and $M$. vespa A/1/7 amplified with MvamF/MvamR. 
using current methodology $(52,62)$. Data in this article also raise concerns about the usefulness of lesion appearance as a diagnostic tool for identifying leaf pathogens. Different necrosis symptoms occur on Phaseolus vulgaris when co-inoculated with both common bacterial blight (Xanthomonas campestris pv. phaseoli) and rust (Uromyces appendiculatus var. appendiculatus) than those observed with single inoculations (78). Even within eucalypts there is considerable host variation with necrosis symptoms for the same Mycosphaerella spp. (8), and M. cryptica and M. nubilosa lesions often coalesce (59). Therefore, the identification of the full complement of Mycosphaerella spp. using lesion appearance, shape, and position of pseudothecia may not be accurate due to the presence of several species in lesions once identified as having only one species.

The first-round amplification with general fungal-specific primers increases sensitivity and avoids time-consuming procedures such as incubation (48). A high degree of species specificity is not essential at this stage, though preferential amplification of fungal DNA improves sensitivity in the nested PCR. Incorporation of an internal amplification control provides additional confidence that negative results are not due to PCR inhibition by some component of the DNA extract, a common problem with plant, particularly eucalypt, DNA (7). The first-round PCR is more critical for enzyme inhibition, because plant components will be considerably diluted by the second round of PCR. The larger size of the IAC product was planned to ensure the IAC amplified less efficiently than the fungal DNA target.

The inability to obtain cloned PCR products of $M$. tasmaniensis and $M$. vespa from leaf samples that had tested positive for these species is puzzling. M. grandis also was lacking in cloned products from five of the samples. This discrepancy may have been caused by preferential amplification of other fungal species with the primers used, though amplification of these three species with ITS1-F/ITS4A was verified from pure fungal DNA. All possible precautions were taken to prevent cross-contamination with PCR product. The variation among the $M$. vespa sequences (Table 5), corresponding with geographic location of the leaf samples, is evidence against cross-contamination. A more likely explanation is that these three species were present in much smaller amounts and testing of a larger number of clones may have been necessary to locate clones containing DNA from these underrepresented species. Development of species-specific realtime PCR may provide further information.

The phylogenetic analysis revealed discrepancies among isolates within species indicative of possible misidentifications. Three isolates received as M. parkii (Table 1) were shown to be two new species quite distinct from $M$. parkii (Fig. 1), although they had produced a Stenella anamorph in culture (P. W. Crous, personal communication). Several GenBank accessions also appeared to come from misnamed isolates (AF173298, AF173299, AF173307, AF468879, AY251086, AY725545, and SAR244260) (Fig. 1). These difficulties are compounded when inaccurately identified cultures are used as reference strains; therefore, culture verification is vital for any studies involving molecular identification.

Phylogenetic analysis showed the close relationships for $M$. grandis and $M$. parva, and $M$. vespa, M. ambiphylla, and M. molleriana, which are all species from Eucalyptus. The high degree of interspecific ITS sequence similarity and lack of alternative well-characterized genomic loci preclude differentiation of each currently recognized species in these groups. Additional studies based on collections from many hosts and geographic regions are needed to confirm that these species are distinct taxa and not merely subpopulations of a single species (22). The ecological niche occupied or pathogenicity factors are secondary taxonomic characters for Mycosphaerella spp. from eucalypts (62). They have been used as part of the rationale for discriminating between $M$. grandis and $M$. parva (12), with $M$. grandis regarded as pathogenic and M. parva as endophytic, though some workers regard these as a single species (18). The

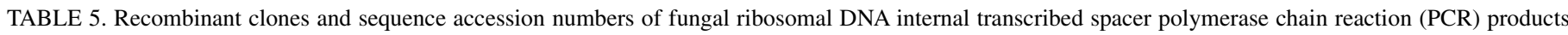
amplified from leaf lesions ${ }^{\mathrm{a}}$

\begin{tabular}{|c|c|c|c|c|c|c|c|}
\hline \multirow[b]{2}{*}{ Leaf sample } & \multirow[b]{2}{*}{ No. of lesions } & \multirow[b]{2}{*}{ Nested PCR ${ }^{b}$} & \multicolumn{4}{|c|}{ Clones } & \multirow[b]{2}{*}{ Accession no. ${ }^{\mathrm{c}}$} \\
\hline & & & M. cryptica & M. nubilosa & M. grandis & Other & \\
\hline 1 & 10 & CGNV & 18 & 5 & $\ldots$ & 9 & DQ465671 \\
\hline 2 & 1 & $\mathrm{C}$ & 4 & $\ldots$ & $\ldots$ & 4 & $\ldots$ \\
\hline 3 & 1 & $\ldots$ & $\ldots$ & $\ldots$ & 1 & 13 & $\ldots$ \\
\hline 4 & 1 & $\mathrm{G}$ & $\ldots$ & $\ldots$ & 7 & 21 & $\ldots$ \\
\hline 5 & 1 & CG & 31 & $\ldots$ & $\ldots$ & 1 & $\ldots$ \\
\hline 6 & 12 & GNV & $\ldots$ & 8 & $\ldots$ & 8 & DQ465671 \\
\hline 7 & 1 & CGTV & 24 & $\ldots$ & 2 & 3 & DQ465672, DQ465674 \\
\hline 8 & 1 & GNTV & $\ldots$ & 1 & $\ldots$ & 15 & DQ465672, DQ465675 \\
\hline 9 & 2 & CGNV & 2 & $\ldots$ & $\ldots$ & 9 & DQ465673 \\
\hline 10 & 6 & $\mathrm{C}$ & 1 & $\ldots$ & $\ldots$ & 13 & $\ldots$ \\
\hline
\end{tabular}

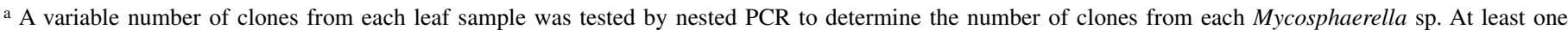
representative of each species from each leaf sample was sequenced to confirm species designation, including one or more clones that were negative for all five Mycosphaerella spp. tested.

${ }^{\mathrm{b}}$ Results for nested PCR: positive for $\mathrm{C}=$ Mycosphaerella cryptica, $\mathrm{G}=$ M. grandis/parva, $\mathrm{N}=$ M. nubilosa, $\mathrm{T}=$ M. tasmaniensis, and $\mathrm{V}=$ M. vespa .

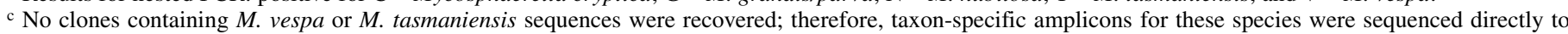
confirm that the product came from the target species. Because the $M$. vespa sequences obtained from samples 1 and 6 , and samples 7 and 8 , were identical, only one GenBank submission was made for each of these sequences.

TABLE 6. Frequency of detection for Mycosphaerella spp. on leaves of Eucalyptus globulus, E. nitens, and E. regnans and stems of E. globulus

\begin{tabular}{|c|c|c|c|c|c|c|}
\hline \multirow[b]{2}{*}{ Tree species } & \multirow[b]{2}{*}{ Sample type, number } & \multicolumn{5}{|c|}{ Frequency $(\%)$} \\
\hline & & Mycosphaerella cryptica & M. grandis & M. nubilosa & M. tasmaniensis & M. vespa \\
\hline E. globulus & Leaf, 60 & 92 & 100 & 83 & 35 & 62 \\
\hline E. nitens & Leaf, 13 & 85 & 100 & 8 & 77 & 23 \\
\hline E. regnans ${ }^{\mathrm{a}}$ & Leaf, 4 & $\mathrm{Y}$ & $\mathrm{Y}$ & $\mathrm{Y}$ & $\mathrm{N}$ & $\mathrm{Y}$ \\
\hline E. globulus & Stem, 7 & 14 & 100 & 0 & 71 & 0 \\
\hline
\end{tabular}

${ }^{\text {a }}$ Due to the small sample size from the native regrowth site, only presence or absence (Y or N, respectively) of Mycosphaerella spp. has been presented. 
ubiquity of $M$. grandis/parva in plantation samples reinforces the need for taxonomic clarification. Additional unnamed isolates and another species from a non-Myrtaceae host (M. bellula) also have high ITS sequence similarity to $M$. grandis and $M$. parva (Fig. 1). Whether this is a single, variable species with a broad host range or many species with highly conserved ITS sequences is unclear. The anamorphs of $M$. grandis and $M$. parva are unknown and there is uncertainty regarding their taxonomic differentiation (15). There is need for a simplified, workable taxonomy (20); however, in the interim, analysis of Mycosphaerella spp. on eucalypts and other woody hosts must accommodate an evolving taxonomic framework.

There is potential to increase the range of tests by developing further primers for more taxa, though additional groups, such as $M$. aurantia and M. africana (Fig. 1), also may be difficult to distinguish using ITS sequences. The failure of most Mycosphaerella spp. from Eucalyptus spp. to produce teleomorphs in culture complicates taxonomic investigations (62). Comparative analysis involving cross inoculations under a range of conditions onto various hosts may indicate variation in teleomorph characteristics of individual isolates. These investigations also could confirm anamorph relationships to teleomorphs, especially for isolates that do not form anamorphs in culture. If further taxonomic studies confirm the validity of currently recognized species that are not differentiated by ITS sequences, another genomic region may be able to provide greater differentiation among those species.

Increasingly, $\beta$-tubulin, elongation factor, actin, calmodulin, histone, and DNA-dependent RNA polymerase II genes are being used in phylogenetic studies of fungi. Phylogenetic analysis based on multiple genes was able to differentiate several species previously all identified as Botryosphaeria dothidea (69). Analysis of elongation factor $1-\alpha$ and $\beta$-tubulin genes supported the synonymy of $M$. juvenis with M. nubilosa (18). Any region that provides phylogenetic discrimination is a suitable candidate for speciesspecific detection. For example, the calmodulin gene was included in a multiple gene phylogeny that provided greater phylogenetic discrimination than ITS sequences for Fusarium spp. in the Gibberella fujikuroi species complex (57). Subsequently, the calmodulin gene was exploited successfully for species-specific detection of two toxigenic Fusarium spp. in asparagus plants (54). As yet, none of these regions have been examined in a large number of Mycosphaerella spp.

The occurrence of highly similar ITS sequences in isolates of distinct species from different host genera raises questions about past evolutionary relationships or recent ones involving new host relationships. This is highlighted by the high similarity among M. aurantia, M. africana (Eucalyptus spp. hosts), M. confusa (Rubus spp.), and M. pini (Pinus spp.). However, the group is distinct from other species infecting Eucalyptus spp. and $M$. dearnessii, another species infecting Pinus, is very different from $M$. pini. In addition, there is significant support for a group containing $M$. intermedia, $M$ marksii (both from eucalypts), and M. musae (from banana) (Fig. 1). In contrast, three poplar-infecting species, M. populi, M. populicola, and M. populorum, form a distinct group. A multiple gene molecular phylogenetic study on carefully isolated and identified isolates of a broad cross-section of Mycosphaerella spp., including those from members of Myrtaceae and other hosts, could be valuable in elucidating evolutionary relationships, possible host jumps, and some of the current taxonomic quandaries.

The Eucalyptus plantation industry is relatively new to Australia and the study of Mycosphaerella spp. in Australia has only recently received attention. Native Australian eucalypt forests mainly consist of mixtures of species of uneven age, in which MLD is usually a minor disease. The establishment of increasing areas of even-aged monocultures provides ideal conditions for epidemics. Crous et al. (19) have suggested that certain Mycosphaerella spp. found on eucalypts in plantations in South Africa, South America, and Europe probably originated in Australasia although, as yet, not all have been found in Australia. The possibility that many species currently known only from overseas are yet to emerge on eucalypt plantations in Australia implies that more serious disease may yet occur.

The capacity to detect Mycosphaerella spp. or taxon groups in samples from plantations and natural forests and to provide detailed and spatially explicit information on the species present within and between trees in a plantation clearly was demonstrated. In our case, this information provided baseline information prior to establishing a rotational length trial for the longterm monitoring of disease impact and the efficacy of different control options. Using standard techniques based on lesion attributes, ascospore germination, and cultural characteristics, rapid determination of the Mycosphaerella spp. associated with the large number of lesions sampled in this study would be impractical. Considering that all the stems and many of the leaves analyzed in the present study had lesions without reproductive structures, the use of classical techniques to rapidly identify species also would be impossible. Spore release from mature fruiting bodies is highly variable, with clusters of spores released by only one or two sporulating species per lesion. Therefore, in the past, Mycosphaerella spp. damage usually has been attributed to these one or two sporulating species $(11,14,25,38,47,50,51,61)$. Although the species detected at the trial site and elsewhere in Tasmania support the findings of a seasonally and geographically more comprehensive survey (51), the detection frequency for all species was much higher in this study, presumably due to the sensitivity and specificity of the molecular detection methods, the ability of the test to detect species in tissue without reproductive structures and to test large numbers of samples. It is evident from this survey that, in Tasmania, where E. globulus is indigenous in native forests and $E$. nitens, which is indigenous to mainland Australia, has been grown in plantations for over 30 years, species compositions are far more complex than original surveys in eucalypt plantations using classical techniques have suggested.

There is substantial evidence from this study to indicate that the co-occurrence of several pathogenic and saprophytic species in a Mycosphaerella leaf lesion is typical for Eucalyptus spp. in Tasmania. Several Mycosphaerella spp. previously have been identified on the same lesions on Myrtaceous and Proteaceous hosts (16). The co-occurrence of several Mycosphaerella spp. in a small leaf volume raises the issue of species-species interaction and their roles as primary or secondary pathogens or saprophytes. In other systems, the co-occurrence of pathogenic species is

TABLE 7. Coexistence of multiple Mycosphaerella spp. in single leaves of Eucalyptus nitens, E. regnans, and E. globulus

\begin{tabular}{|c|c|c|c|c|c|c|}
\hline \multirow[b]{2}{*}{ Tree species } & \multirow[b]{2}{*}{ Sample type, number } & \multicolumn{5}{|c|}{ Percentage of samples with the corresponding number of Mycosphaerella spp. } \\
\hline & & 1 & 2 & 3 & 4 & 5 \\
\hline E. nitens & Leaf, 13 & 0 & 22 & 67 & 11 & 0 \\
\hline E. globulus & Leaf, 60 & 0 & 10 & 37 & 33 & 20 \\
\hline E. regnans & Leaf, 4 & $\mathrm{~N}$ & $\mathrm{Y}$ & $\mathrm{Y}$ & $\mathrm{N}$ & $\mathrm{N}$ \\
\hline E. globulus & Stem, 7 & 29 & 57 & 14 & 0 & 0 \\
\hline
\end{tabular}

a Due to the small sample size from the native regrowth site, only presence or absence (Y or N, respectively) of Mycosphaerella spp. has been presented. 
common. These highly characterized disease systems include Fusarium head blight in cereals $(55,56)$, Melampsora rust on willow and poplar (66), sooty blotch in apple trees (41), and the Dutch elm disease complex of Ophiostoma ulmi, O. novo-ulmi, and $O$. himal-ulmi (36). There is limited knowledge of the pathogenicity of most Mycosphaerella spp., on eucalypts, including $M$. tasmaniensis and $M$. vespa, which have been isolated frequently in past surveys in Tasmania $(51,77)$. The ubiquity of M. grandis/parva in the leaf samples tested raises questions about its possible role in pathogenicity. M. parva is considered to be endophytic and there are doubts about the taxonomic distinction between $M$. parva and $M$. grandis (15). M. grandis was described as a leaf pathogen by Carnegie and Keane (12). The detection of only $M$. grandis/parva in two stem lesions indicates their potential role as a pathogen in stems.

This study has illustrated that nested PCR is a suitable technique for differentiating Mycosphaerella spp. in prenecrotic and prereproductive lesions and has provided a rapid and accurate method for Mycosphaerella spp. identification to validate disease surveys and research trials. Unlike classical methods, the detection technique enables rapid processing of large sample numbers and provides more comprehensive and reliable data. The nested PCR is a reliable and cost-effective method, useful for studies on the developmental ecology and epidemiology of MLD. It also may provide valuable information for the advance of management strategies for MLD on eucalypt plantations. The species-specific primer pairs described here also meet the requirements of an effective quarantine tool, providing rapid, direct detection of pathogens of concern from asymptomatic tissue, including germ plasm (74). This capability also may assist in nursery quality assurance that Mycosphaerella pathogens are eliminated and not merely suppressed prior to certification of disease-free seedlings and planting stocks. Such a move may help minimize the risk to industry of unwittingly introducing disease, particularly cryptic infections, into plantations at their most vulnerable stage.

\section{ACKNOWLEDGMENTS}

We thank M. Dudzinski and R. Gibbs (CSIRO, Australia), M. Dick (SCION), A. Alfenas (Federal University of Viçosa, Brazil), and A. Carnegie (State Forests New South Wales, Australia) for providing isolates.

\section{LITERATURE CITED}

1. Abbott, I., van Heurck, P., Burbidge, T., and Williams, M. 1993. Damage caused by insects and fungi to eucalypt foliage: Spatial and temporal patterns in Mediterranean forest of Western Australia. For. Ecol. Manage. 58:85-110.

2. Atkins, S. D., and Clark, I. M. 2004. Fungal molecular diagnostics: A mini review. J. Appl. Genet. 45:3-15.

3. Bélec, L., Authier, J., Eliezer-Vanerot, M.-C., Piédouillet, C., Moamed, A. S., and Gherardi, R. K. 1998. Myoglobin as a polymerase chain reaction (PCR) inhibitor: A limitation for PCR from skeletal muscle tissue avoided by the use of Thermus thermophilus polymerase. Muscle Nerve 21:10641067.

4. Braid, M. D., Daniels, L. M., and Kitts, C. L. 2003. Removal of PCR inhibitors from soil DNA by chemical flocculation. J. Microbiol. Methods 52:389-393.

5. Braun, U., Crous, P. W., Dugan, F., Groenewald, J. Z., and De Hoog, G. S. 2003. Phylogeny and taxonomy of Cladosporium-like hyphomycetes, including Davidiella gen. nov., the teleomorph of Cladosporium s. str. Mycol. Prog. 2:3-18.

6. Braun, U., Crous, P., and Kamal, D. C. 2003. New species of Pseudocercospora, Pseudocercosporella, Ramularia and Stenella (cercosporoid hyphomycetes). Mycol. Prog. 2:197-208.

7. Byrne, M., Moran, G. F., Murrell, J. C., and Tibbits, W. N. 1994. Detection and inheritance of RFLPs in Eucalyptus nitens. Theor. Appl. Genet. 89:397-402.

8. Carnegie, A. J., and Ades, P. K. 2002. The proportion of leaf spots caused by Mycosphaerella cryptica and M. nubilosa on Eucalyptus globulus, E. nitens and their F1 hybrids in a family trial in Tasmania, Australia. Aust.
Mycol. 21:53-63.

9. Carnegie, A. J., and Ades, P. K. 2002. Mycosphaerella leaf disease reduces growth of plantation-grown Eucalyptus globulus. Aust. For. 66:113-119.

10. Carnegie, A. J., Ades, P. K., Keane, P. J., and Smith, I. W. 1994. Variation in susceptibility of Eucalyptus globulus provenances to Mycosphaerella leaf disease. Can. J. For. Res. 24:1751-1757.

11. Carnegie, A. J., Ades, P. K., Keane, P. J., and Smith, I. W. 1998. Mycosphaerella diseases of juvenile foliage in a eucalypt species and provenance trial in Victoria, Australia. Aust. For. 61:190-194.

12. Carnegie, A. J., and Keane, P. J. 1994. Further Mycosphaerella species associated with leaf diseases of Eucalyptus. Mycol. Res. 98:413-418.

13. Carnegie, A. J., and Keane, P. J. 1998. Mycosphaerella vespa sp. nov. from diseased Eucalyptus leaves in Australia. Mycol. Res. 102:12741276.

14. Carnegie, A. J., Keane, P. J., and Podger, F. D. 1997. The impact of three species of Mycosphaerella newly recorded on Eucalyptus in Western Australia. Aust. Plant Pathol. 26:71-77.

15. Crous, P. W. 1998. Mycosphaerella species and their anamorphs associated with leaf spot diseases of Eucalyptus. Mycological Memoir No. 21. The American Phytopathological Society, St. Paul, MN.

16. Crous, P. W. 2000. An improved technique for obtaining single ascospore cultures of ascomycetes. Mycologist 14:101-104.

17. Crous, P. W., Aptroot, A., Kang, J.-C., Braun, U., and Wingfield, M. J. 2000. The genus Mycosphaerella and its anamorphs. Stud. Mycol. 45:107-121.

18. Crous, P. W., Groenewald, J. Z. Mansilla, J. P., Hunter, G. C., and Wingfield, M. J. 2004. Phylogenetic reassessment of Mycosphaerella spp. and their anamorphs occurring on Eucalyptus. Stud. Mycol. 50:195-214.

19. Crous, P. W., Hong, L., Wingfield, B. D., and Wingfield, M. J. 2001. ITS rDNA phylogeny of selected Mycosphaerella species and their anamorphs occurring on Myrtaceae. Mycol. Res. 105:425-431

20. Crous, P. W., Kang, J. C., and Braun, U. 2001. A phylogenetic redefinition of anamorph genera in Mycosphaerella based on ITS rDNA sequence and morphology. Mycologia 93:1081-1101.

21. Crous, P. W., Wingfield, M. J., Mohammed, C., and Yuan, Z. Q. 1998. New foliar pathogens of Eucalyptus from Australia and Indonesia. Mycol. Res. 102:527-532.

22. Dick, M., and Dobbie, K. 2001. Mycosphaerella suberosa and M. intermedia sp. nov. on Eucalyptus in New Zealand. N.Z. J. Bot. 39:269-276.

23. Dick, M., and Gadgil, P. D. 1983. Page 7 in: Forest Pathology in New Zealand 1. Eucalyptus Leaf Spots. New Zealand Forest Service, Rotorua, NZ.

24. Dieffenbach, C. W., Lowe, T. M. J., and Dveksler, G. S. 1995. General concepts for PCR primer design. Pages 133-142 in: PCR Primer: A Laboratory Manual. C. W. Dieffenbach and G. S. Dveksler, eds. Cold Spring Harbor Laboratory, Cold Spring Harbor, NY.

25. Dungey, H. S., Potts, B. M., Carnegie, A. J., and Ades, P. K. 1997. Mycosphaerella leaf disease: Genetic variation in damage to Eucalyptus nitens, Eucalyptus globulus, and their F1 hybrid. Can. J. For. Res. 27:750759.

26. Felsenstein, J. 1989. PHYLIP-Phylogeny Inference Package (Version 3.2). Cladistics 5:164-166

27. Fraaije, B. A., Lovell, D. J., Rohel, E. A., and Hollomon, D. W. 1999. Rapid detection and diagnosis of Septoria tritici epidemics in wheat using a polymerase chain reaction/PicoGreen assay. J. Appl. Microbiol. 86:701708.

28. Gadgil, P. D., Wardlaw, T. J., Ferreira, F. A., Sharma, J. K., Dick, M. A., Wingfield, M. J., and Crous, P. W. 2000. Management of disease in eucalypt plantations. Pages 519-529 in: Diseases and Pathogens of Eucalypts. P. J. Keane, G. A. Kile, F. D. Podger, and B. N. Brown, eds. CSIRO Publishing, Collingwood, Australia.

29. Gardes, M., and Bruns, T. D. 1993. ITS primers with enhanced specificity for basidiomycetes-application to the identification of mycorrhizae and rusts. Mol. Ecol. 2:113-118.

30. Gardner, R., Swain, T., and Norris, C. 2003. Eucalypt species and provenance trials in the Southern Cape: Results at four years of age. ICFR Bulletin Series (no. 11/2003). Institute for Commercial Forestry Research, Scottsville, South Africa.

31. Glen, M., Tommerup, I. C., Bougher, N. L., and O’Brien, P. A. 2002. Are Sebacinaceae common and widespread ectomycorrhizal associates of Eucalyptus species in Australian forests? Mycorrhiza 12:243-247.

32. Glass, N. L., and Donaldson, G. C. 1995. Development of primer sets designed for use with the PCR to amplify conserved genes from filamentous ascomycetes. Appl. Environ. Microbiol. 61:1323-1330.

33. Goodwin, S. B., Dunkle, L. D., and Zismann, V. L. 2001. Phylogenetic analysis of Cercospora and Mycosphaerella based on the internal transcribed spacer region of ribosomal DNA. Phytopathology 91:648-658.

34. Grant, M. A. 2003. Evaluation of methods to improve detection of Escherichia coli $\mathrm{O} 157: \mathrm{H} 7$ in fresh produce by multiplex polymerase 
chain reaction. J. Food Prot. 66:18-24.

35. Hantula, J., and Vainio, E. 2003. Specific primers for the differentiation of Heterobasidion annosum (s. str.) and H. parviporum infected stumps in Northern Europe. Silva Fenn. 37:181-187.

36. Harrington, T. C., McNew, D., Steimel, J., Hofstra, D., and Farrell, R. 2001. Phylogeny and taxonomy of the Ophiostoma piceae complex and the Dutch elm disease fungi. Mycologia 93:111-136.

37. Holden, M. J., Blasic, J. R., Jr., Bussjaeger, L., Kao, C. A., Shokere, L. A., Kendall, D. C., Freese, L., and Jenkins, G. R. 2003. Evaluation of extraction methodologies for corn kernel (Zea mays) DNA for detection of trace amounts of biotechnology-derived DNA. J. Agric. Food Chem. $51: 2468-2474$

38. Hood, I. A., Gardner, J. F., Kimberley, M. O., and Molony, K. 2002. Variation among eucalypt species in early susceptibility to the leaf spot fungi Phaeophleospora eucalypti and Mycosphaerella spp. N.Z. J. For. Sci. 32:235-255

39. Hunter, G. C., Roux, J., Wingfield, B. D., Crous, P. W., and Wingfield, M. J. 2004. Mycosphaerella species causing leaf disease in South African Eucalyptus plantations. Mycol. Res. 108:672-681.

40. Johanson, A., and Jeger, M. J. 1993. Use of PCR for detection of Mycosphaerella fijiensis and M. musicola, the causal agents of Sigatoka leaf spots in banana and plantain. Mycol. Res. 97:670-674.

41. Johnson, E. M., Sutton, T. B., and Hodges, C. S. 1996. Peltaster fructicola: A new species in the complex of fungi causing apple sooty blotch disease. Mycologia 88:114-120.

42. Kennedy, R., Wakeham, A. J., Byrne, K. G., Meyer, U. M., and Dewey, F. M. 2000. A new method to monitor airborne inoculum of the fungal plant pathogens Mycosphaerella brassicicola and Botrytis cinerea. Appl. Environ. Microbiol. 66:2996-3003.

43. Kularatne, H. A. G. C., Lawrie, A. C., Barber, P. A., and Keane, P. J. 2004. A specific primer PCR and RFLP assay for the rapid detection and differentiation in planta of some Mycosphaerella species associated with foliar diseases of Eucalyptus globulus. Mycol. Res. 108:1476-1493.

44. Langrell, S. R. H. 2005. Development of a nested PCR detection procedure for Nectria fuckeliana direct from Norway spruce bark extracts. FEMS Microbiol. Lett. 242:185-193.

45. Langrell, S. R. H., and Barbara, D. J. 2001. Development of a magnetic capture hybridization system to detect Nectria galligena from woody tissue. Plant Mol. Biol. Rep. 19:1-8.

46. Larena, I., Salazar, O., González, V., Julián, M. C., and Rubio, V. 1999. Design of a primer for ribosomal DNA internal transcribed spacers with enhanced specificity for ascomycetes. J. Biotechnol. 75:187-194.

47. Lundquist, J. E., and Purnell, R. C. 1987. Effects of Mycosphaerella leaf spot on growth of Eucalyptus nitens. Plant Dis. 71:1025-1029.

48. Manfreda, G., De Cesare, A., Bondioli, V., and Franchini, A. 2003. Comparison of the BAX System with a multiplex PCR method for simultaneous detection and identification of Campylobacter jejuni and Campylobacter coli in environmental samples. Int. J. Food Microbiol. 87:271-278.

49. Maxwell, A., Dell, B., Neumeister-Kemp, G. G., and Hardy, G. E. S. J. 2003. Mycosphaerella species associated with Eucalyptus in southwestern Australia: New species, new records and a key. Mycol. Res. 107:351-359.

50. Milgate, A. W., Potts, B. M., Joyce, K., Mohammed, C., and Vaillancourt, R. E. 2005. Genetic variation in Eucalyptus globulus for susceptibility to Mycosphaerella nubilosa and its association with tree growth. Australas. Plant Pathol. 34:11-18.

51. Milgate, A. W., Yuan, Z. Q., Vaillancourt, R. E., and Mohammed, C. 2001. Mycosphaerella species occurring on Eucalyptus globulus and Eucalyptus nitens plantations of Tasmania, Australia. For. Pathol. 31:53-63.

52. Mohammed, C., Wardlaw, T., Smith, A., Pinkard, E., Battaglia, M., Glen, M., Tommerup, I., Potts, B., and Vaillancourt, R. 2003. Mycosphaerella leaf diseases of temperate eucalypts around the Southern Pacific rim. N. Z. J. For. Sci. 33:362-372.

53. Morel, O., Robin, C., and Langrell, S. R. H. 2003. Simultaneous detection and identification of Phytophthora cinnamomi and P. cambivora direct from French chestnut grove soils by multiplex PCR. Pages 173-181 in: Proc. Second Int. Meet. Phytophthora in Forests and Natural Ecosystems. Murdoch University Print, Murdoch, Australia.

54. Mulè, G., Susca, A., Stea, G., and Moretti, A. 2004. Specific detection of the toxigenic species Fusarium proliferatum and $F$. oxysporum from asparagus plants using primers based on calmodulin gene sequences. FEMS Microbiol. Lett. 230:235-240.

55. Nicholson, P., Chandler, E., Draeger, R. C., Gosman, N. E., Simpson, D. R., Thomsett, M., and Wilson, A. H. 2003. Molecular tools to study epidemiology and toxicology of Fusarium head blight of cereals. Eur. J.
Plant Pathol. 109:691-703.

56. Nicholson, P., Simpson, D. R., Weston, G., Rezanoor, H. N., Lees, A. K., Parry, D. W., and Joyce, D. 1998. Detection and quantification of $F u$ sarium culmorum and Fusarium graminearum in cereals using PCR assays. Phys. Mol. Plant Pathol. 53:17-37.

57. O'Donnell, K., Nirenberg, H. I., Aohi, T., and Cigelnik, E. 2000. A multigene phylogeny of the Gibberella fujikuroi species complex: Detection of additional phylogenetically distinct species. Mycoscience 41:61-78.

58. Old, K. M., Wingfield, M. J., and Yuan, Z. Q. 2003. A Manual of Diseases of Eucalypts in South-East Asia. CIFOR, Jakarta, Indonesia.

59. Park, R. F., and Keane, P. J. 1982. Three Mycosphaerella species from leaf diseases of Eucalyptus. Trans. Br. Mycol. Soc. 79:95-100.

60. Park, R. F., and Keane, P. J. 1982. Leaf diseases of Eucalyptus associated with Mycosphaerella species. Trans. Br. Mycol. Soc. 79:101-115.

61. Park, R. F., and Keane, P. J. 1987. Spore production by Mycosphaerella species causing leaf diseases of Eucalyptus. Trans. Br. Mycol. Soc. 89:461-470

62. Park, R. F., Keane, P. J., Wingfield, M. J., and Crous, P. W. 2000. Fungal diseases of eucalypt foliage. Pages 153-239 in: Diseases and Pathogens of Eucalypts. P. J. Keane, G. A. Kile, F. D. Podger, and B. N. Brown, eds. CSIRO Publishing, Collingwood, Australia.

63. Poussier, S., Chéron, J.-J., Couteau, A., and Luisetti, J. 2002. Evaluation of procedures for reliable PCR detection of Ralstonia solanacearum in common natural substrates. J. Microbiol. Methods 51:349-359.

64. Pretorius, M. C., Crous, P. W., Groenewald, J. Z., and Braun, U. 2003. Phylogeny of some cercosporoid fungi from Citrus. Sydowia 55:286-305.

65. Raeder, U., and Broda, P. 1985. Rapid preparation of DNA from filamentous fungi. Lett. Appl. Microbiol. 1:17-20.

66. Royle, D. J., and Ostry, M. E. 1995. Disease and pest control in the bioenergy crops Poplar and Willow. Biomass Bioenergy 9:69-79.

67. Schaad, N. W., Frederick, R. D., Shaw, J., Schneider, W. L., Hickson, R., Petrillo, M. D., and Luster, D. G. 2003. Advances in molecular-based diagnostics in meeting crop biosecurity and phytosanitary issues. Annu. Rev. Phytopathol. 41:305-324.

68. Schmidt, H., Ehrmann, M., Vogel, R. F., Taniwaki, M. H., and Niessen, L. 2003. Molecular typing of Aspergillus ochraceus and construction of species-specific SCAR-primers based on AFLP. Syst. Appl. Microbiol. 26:138-146.

69. Slippers, B., Crous, P. W., Denman, S., Coutinho, T. A., Wingfield, B. D., and Wingfield, M. J. 2004. Combined multiple gene genealogies and phenotypic characters differentiate several species previously identified as Botryosphaeria dothidea. Mycologia 96:83-101.

70. Stewart, E. L., Liu, Z. W., Crous, P. W., and Szabo, L. J. 1999. Phylogenetic relationships among some cercosporoid anamorphs of Mycosphaerella based on rDNA sequence analysis. Mycol. Res. 103:1491-1499.

71. Stone, C., Matuski, M., and Carnegie, A. 2003. Pest and Disease Assessment in Young Eucalypt Plantations: Field Manual for Using the Crown Damage Index. M. Parsons, ed. Bureau Rural Sciences, Canberra, Australia.

72. Taylor, E. H. A., Stevens, E. A., Bates, J. A., Morreale, G., Lee, D., Kenyon, D. M., and Thomas, J. E. 2001. Rapid-cycle PCR detection of Pyrenophora graminea from barley seed. Plant Pathol. 50:347-355.

73. Thompson, J. D., Higgins, D. G., and Gibson, T. J. 1994: CLUSTAL W: Improving the sensitivity of progressive multiple sequence alignment through sequence weighting, position-specific gap penalties and weight matrix choice. Nucleic Acids Res. 22:4673-4680.

74. Tommerup, I. C., Alfenas, A. C., and Old, K. M. 2003. Guava rust in Brazil - a threat to Eucalyptus and other Myrtaceae. N.Z. J. For. Sci. $33: 420-428$

75. Udovicic, F., and Murphy, D. J. 2002. Successful DNA amplification from Acacia (Leguminosae) and other refractory Australian plants and fungi using a nested/semi-nested PCR protocol. Muelleria 16:47-53.

76. White, T. J., Bruns, T., Lee, S., and Taylor, J. 1990. Amplification and direct sequencing of fungal ribosomal RNA genes for phylogenetics. Pages 315-322 in: PCR Protocols: A Guide to Methods and Applications. M. A. Innis, D. H. Gelfand, J. J. Sninsky, and T. J. White, eds. Academic Press, San Diego, CA.

77. Yuan, Z. Q. 1999. Fungi associated with disease detected during health surveys of Eucalypt plantations in Tasmania. School of Agricultural Science, University of Tasmania, Australia.

78. Zaiter, H. Z., Coyne, D. P., and Steadman, J. R. 1990. Co-inoculation effects of pathogens causing common bacterial blight, rust and bean common mosaic in Phaseolus vulgaris. J. Am. Soc. Hortic. Sci. 115: $319-323$ 